S Graham, Rlchard $J$

632.951

U8 $f 1$

1958
Effects of

forest Insect

spraying on trout

and aquatic

insects in some

Montana streams

\title{
EFFECTS OF FOREST INSECT SPRAYING ON TROUT AND AQUATIC INSECTS IN SOME MONTANA STREAMS
}

\section{STATE DOCUMENTS COLLECTION}

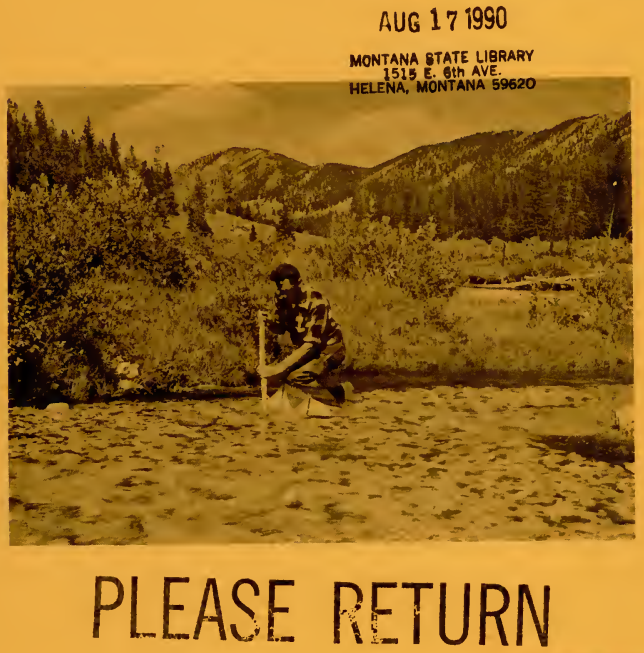


MONTANA STATE LIBRARY

S 632.951 UBepr 1956 c. 1 Cope

Effects of forest insect spraying on tro

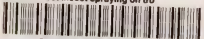

30864000776875

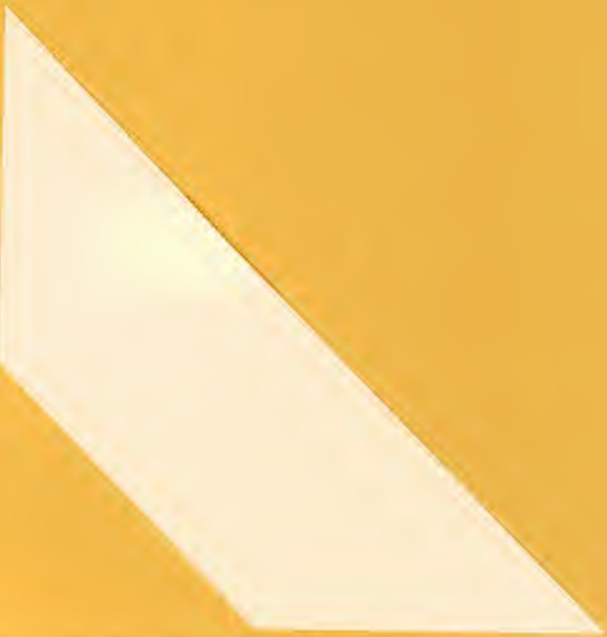




\section{FFFECTS OF FOREST INSECT SPRAYING}

ON TROUT AND AQUATIC INSECTS

IN SOME MONTANA STREAMS

FIIAL REPORT

APPROVED:

Dira b. Le

Dr. Oliver B. Cope, Chief

Rocky Mountain Sport Fishery

Investigations

U. S. Fish \& Wildlife Service

Logan, Utah

0.0 .0 (beine)

A. A. O'Cloire, Director

Montana State Fish \& Geme Department

Helena, Montana

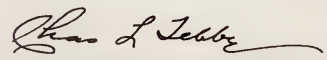

Chas. L. Tebbe, Regional Forester

U. S. Forest Service

Milssoula, Montana 


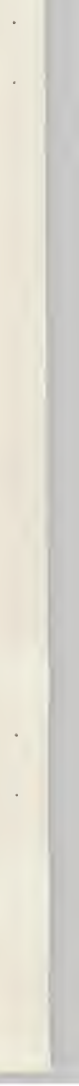




\section{FOREWORD}

The U. S. Fish \& Wildlife Service, the Montana State Fish \& Game Department and the U. S. Forest Service organized a cooperative administrative study in 1956 to test the effects of aerial forest spraying operations on several Montana trout streams. In 1957 additional information was obtained on fish populations and the population recovery of aquatic invertebrates in the sampled streams.

This report includes the basic data submitted by Oliver B. Cope I/ and Barry C. Park 27 in their 1956 Progress Report and the 1957 follow-up data collected by personnel of the Montana State Fish \& Game Department and the U. S. Forest Service. R. J. Graham and David 0. Scott were the respective coordinators in 1957 and are the authors of this report. Another administrative study was initiated for the Ruby River in 1957. A report on this work is being prepared and will appear under separate cover.

A selected list of references dealing with studies on DDT-fish relationships is included at the end of the report as a guide for workers interested in the results of other investigations.

1/ Dr. Oliver B. Cope, Chief, Rocky Mountain Sport Fishery Investigations, U. S. Fish \& Wildlife Service, Logan, Utah.

2/ Barry C. Park, Forester, Division of Range \& Wildlife Management, U. S. Forest Service, Missoula, Montana. 

SUMMARY AND CONCLUSIONS ..................... I

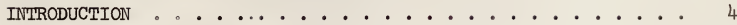

Acknowledgments ................. 4 METHODS . . . . . . . . . . . . . . . . . 7 DDT Spray ................... 7 Trout Population Index and Condition . . . . . . . . 7 Aquatic Invertebrates ............... 8 INTENSIVE STREAM STUDIES ...................... 8 Analysis of DDT in Water ............ 14 Trout Population Index and Condition Factor . . . . . 15 Fish Live Cars . . . . . . . . . . . . 25 Analysis of Trout Tissues .............. 16 Trout Stomach Food Analysis . . . . . . . . . . 16 Drift Samples .................. 19 Stream Bottom Samples .............. 22 Aquatic Insect Live Cars . . . . . . . . . . . 26 Sweep Net Collections .............. 26 EXIENSIVE STREAM STUDIES ................ 27 Aquatic Insects . . . . . . . . . . 27

Fish Populations . . . . . . . . . . . 28 REFERENCES . . . . . . . . . . . . . . . 29

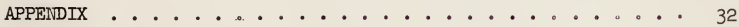




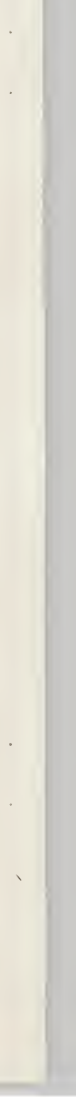


This cooperative study was established to facilitate comprehensive research needed in conjunction with the use of DDT aerial sprays in western forest areas. The primary purpose of this interim administrative study was to obtain information as quickly as possible for immediate use in conjunction with a current spruce budworm control program in Montana. The immediate objective was to determine the effect of the aerial application of one pound of DDT per acre on the fish resources and ways of minimizing any possible detrimental effect.

Stream shocking operations to determine fish abundance, and stream bottom sampling to determine the amounts of fish food organisms, were carried on prior to and following spraying on 13 mountain trout streams within three national forests in Montana where spraying was done in 1956.

Two streams, Canyon Creek and Trapper Creek, were studied more intensively than the others. The results obtained on these streams in 1956-1957 were as follows:

1. Hydorgen-ion concentrations and methyl orange alkalinity determination were found to be within ranges considered favorable for flsh and aquatic insects.

2. Chemical analysis of one water sample taken 27 hours after spraying on July 2, 1956, showed no measurable amount of DDT.

3. Chemical analysis of one water sample taken on July 3, 1956, after a 1.2 inch rainfall, showed no leaching effect of DDT into the stream.

4. No trout mortality was observed by crews taking samples at frequent intervals in the summer of 1956. In 1957 more limited observations also showed no fish mortality.

5. Numerous yearling brook trout were collected in Trapper Creek in 1957, showing a survival of young-of-the-year fish of 1956.

6. Trout gorged themselves on the immature and adult insects killed by the DDT during the five-day period when these dead insects were being carried downstream, but no direct mortality of fish was observed.

7. There was a slight decrease in trout numbers on both Trapper Creek and Canyon Creek between August 1956 and August 1957, but the decline may or may not have been the result of normal population fluctuations.

8. Live brook trout, taken 16 months after the spraying of July 2, 1956, were chemically analyzed and found to contain DDT. 
9. Aquatic bottom invertebrates and adult aquatic insects (aerial) were materially reduced by the DDT spray.

10. Recovery of insects on Trapper Creek appeared to be near normal by September 1957 .

11. On Canyon Creek the September 1957 volumes of insects were considerably greater than the September 1956 volumes. However, September 1956-1957 volumes in control stations in the spray area were greater than prespray June volumes, while fall samples (1957) contained less insects than prespray spring samples, which would indicate only partial recovery.

12. Whether individual insect species became reestablished in the same proportion as they were found in the prespray samples was not determined.

13. The effect of the aerial DDT spray upon stream-bottom insects in live cars decreased with the distance below the sprayed area. They appeared to be normal $1 \frac{1}{2}$ miles below the spray area on Trapper Creek.

14. Trout in sprayed sections where the bottom fauna was depleted fed on terrestrial insects and midge fly larvae.

15. Condition factors of trout in both streams were higher in 1957 than in 1956.

Results on 11 other streams studied less intensively were as follows:

1. The DDT spray caused a marked loss of aquatic insects in sprayed sections.

2. On four of these streams quantitative recovery of aquatic insects had progressed upward considerably by the end of the second summer.

3. Very few aquatic organisms were found in the sprayed stations of the fifth stream (Sheep Creek) in the second summer.

4. The censuses did not reveal any fish mortality during the summer of the spraying (late in June and early July).

5. In the second summer, fish populations on three of the streams approximated those of the previous year.

6. On two streams (North Fork Musselshell River and Sheep Creek) game fish reductions of about $70 \%$ and $80 \%$ respectively, occurred between August 1956 and August 1957.

7. Observations on Sheep Creek and North Fork Musselshell River indicate there may be delayed effects and reductions can occur which may not be observed by the public. 
The following suggestions are made to minimize the effect of DDT aerial spraying on fish resources:

1. Undertake, if feasible, spruce budworm control programs before infestations cover large acreages of forest land.

2. Spray spruce budworm infestations before they reach upper drainage areas.

3. Spray around the edge of lakes when wind velocity is low or nonexistent.

4. Spray the forest across small, fast streams to avoid double dosages from drift often associated with controur spraying in steep-sided drainages.

5. Plan spray blocks to eliminate airplane turns over the streams.

6. Spray the larger streams on the contour, but keep the spray out of the water. Careful operational planning is essential.

7. Should mechanical difficulties be encountered on aircraft, necessitating discharge of the spray load, make every effort to keep the spray away from streams or lakes. 
Although the presence of the spruce budworm, Choristoneura fumiferana, (Clem.) was reported in Montana as early as 1923 , only since 1947 has the infestation become aggressively epidemic. By 1951 the severity of the infestation had not abated and timber, watershed, and recreation values were in jeopardy. A decision was made on recommendation of the Forest Service to control the spruce budworm by applying one pound of DDT per acre on small, heavily infested acreages to save defollated trees and prevent tree mortality. Control was initiated in the summer of 1952 on 12,000 acres within the Bitterroot National Forest. This project was followed by similar "hot-spot" spray programs on the Helena and Nezperce National Forests and Yellowstone Park in 1953.

Because of the continued severity of the epidemic, a spray project covering 132,856 acres was satisfactorily completed in and adjacent to the Yellowstone National Park in 1955. This spray program was carried on by the U. S. Forest Service, the U. S. National Park Service and the Montana State Forestry Department for the control of spruce budworm in Douglas-fir.

Dead fish were found in the Yellowstone River in the fall of 1955 in such numbers that considerable concern was felt by sportsmen, biologists, and fish and game administrators. In seeking an explanation for this unusual mortality, some observers thought it to be related to a July 1955 aerial application of DDT to widespread forest areas in the Gallatin National Forest and Yellowstone National Park.

When another major spruce budworm control project of 885,332 acres was planned for 1956, the Montana State Fish and Game Department, the U. S. Fish and Wildlife Service and the U. S. Forest Service cooperatively selected 13 streams within the proposed aerial spray boundaries for an administrative study on the effects of DDT on aquatic life. Fish shocking to determine indices of fish populations and sampling of aquatic invertebrates to determine amounts of fish food were carried on before and after spraying. These streams were located in the Helena, Beaverhead and Lewis \& Clark National Forests in Montana.

In 1957 follow-up data were taken on seven of the streams on which substantial information was obtained in 1956. (Map I.) Two of these streams, Canyon Creek and Trapper Creek on the Beaverhead National Forest, were again studied more intensively than the others.

\section{Acknowledgments}

Both the 1956 Progress Report published in June 1957, and this final report were reviewed by George Holton, Chief Fisheries Management Biologist, Montana State Fish and Game Department, and Clarence Hoffmann, Assistant Director, Entomology Research Division, Agricultural Research 


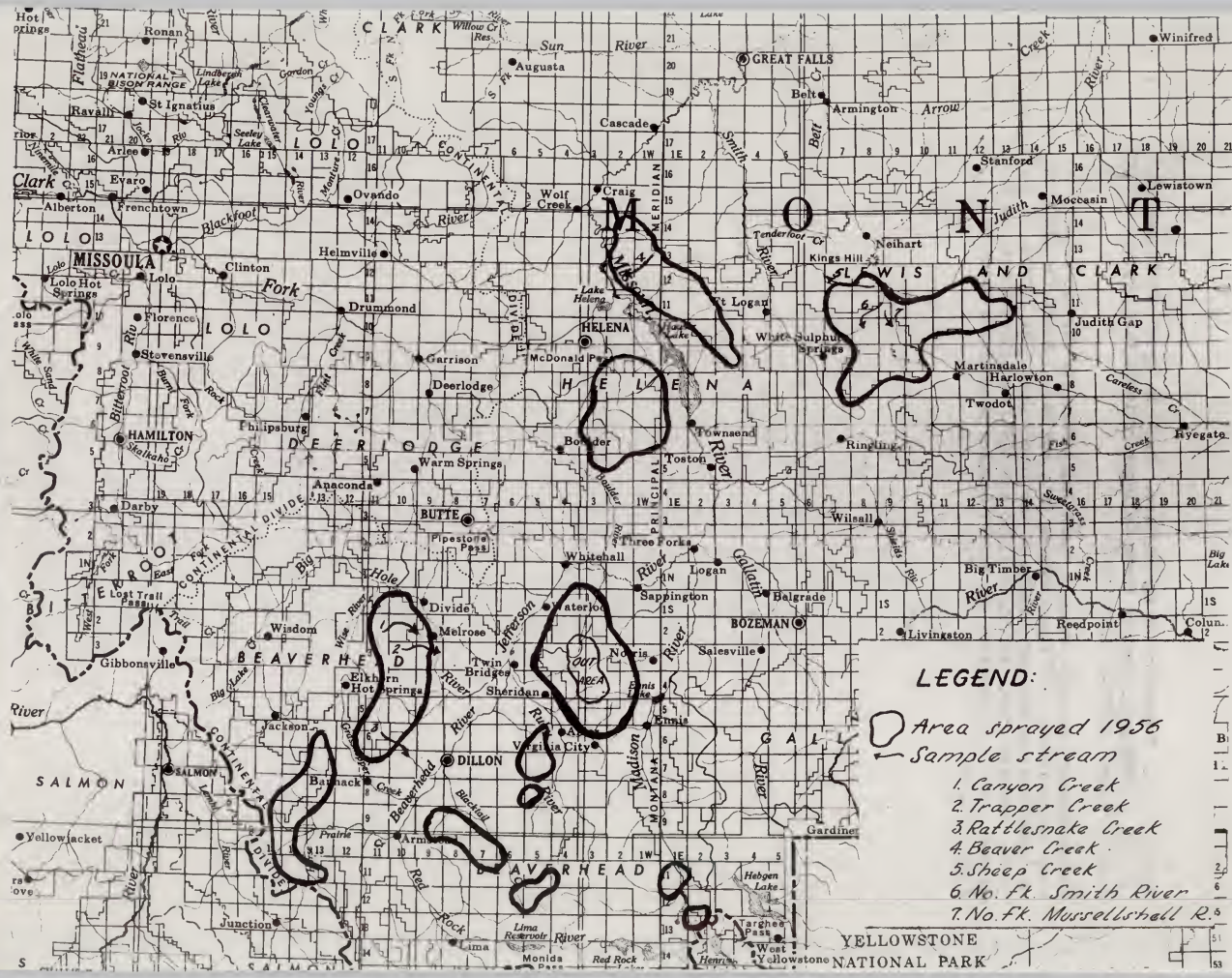


Service, U. S. Department of Agriculture. C. J. D. Brown, Professor of Zoology \& Entomology, Montana State College, reviewed this report. Their cooperation was greatly appreciated.

The cooperating agencles wish to thank James Posewitz for his work on the compilation of the $1956 \mathrm{flsh}$ shocking data and Danlel Block for his work on identification and compllation of the insect data. As foreman of field crews, Posewitz (1956) and Block (1956 and 1957) contributed much to the project. The illustrations are Forest Service photographs taken by Barry C. Park. 
METHODS

The general plan of the study featured two approaches in measuring the effects of DDT on stream animals. The intensive part of the study was conducted on Canyon Creek and Trapper Creek only, and emphasized frequent sampling, careful and precise observations, and daily measurements. The extensive study involved fewer samples and was done over a wide area, the object being to secure measurements on a variety of stream situations. The latter work was done on Prickly Pear, Trout, Beaver, Birch, Rock, Rattlesnake, Crow, McClellan, and Sheep Creeks and the North Fork Musselshell River and North Fork Smith River. Canyon Creek, Trapper Creek and five of the other streams were selected for study in 1957 to observe any delayed effects on fish and the recovery rate of bottom organisms.

\section{DDT Spray}

The spray consisted of one pound of DDT dissolved in 1.25 quarts of hydrocarbon solvent and diluted in sufficient fuel oil to make one gallon of insecticide. Airplanes were used to disperse the spray over the forest during June and July, 1956 at the rate of one gallon per acre (one pound of DDT per acre). Varying amounts of spray reached the ground and water surfaces. (On Trapper Creek an average of .19 pound of DDT per acre and on Canyon Creek . 32 pound of DDT per acre reached the water.) A measurement of 0.20 pound of DDT per acre on the ground was the objective for obtaining satisfactory spruce budworm mortality.

The amount of DDT reaching stream-study sections was determined by placing oil-sensitive dye cards at 4-chain intervals on spray check lines running at right angles to the spray swath. On the two intensively sampled streams, additional cards were placed along the edge of the stream in study sections. Seven cards were placed in each study section and one card on each of 16 live cars, for a total of 93 additional cards. The cards were put in place just prior to spray day, July 2, 1956.

\section{Trout Population Index and Condition}

No attempt was made to determine the total fish population of any streams, but only an index before and after spraying. Observations were limited to game fish which were primarily trout. A portable 500-watt alternating current generator producing a maximum of 240 volts provided the electrical energy to stun fish. Voltage used was dependent on stream conditions, but it was kept as low as possible to avoid injury to fish. Each section was 300 feet long and was blocked at both ends with nets. In general, a section was shocked three times during a sampling period. Stunned fish were caught with dip nets and placed in holding pens located in quiet water. (Figures 1 and 2.) Captured fish were anesthetized in a 0.5 percent solution of urethane before weighing and measuring. (Figures 3 and 4.) Total lengths to the nearest 0.1 of an inch and weights to the nearest 0.01 of a pound were taken. Only fish at least three inches long 
were used in population index numbers, since fish smaller than this size could not be efficiently collected. Condition factors (relative plumpness) were determined only for fish four inches or longer. Condition factor (c) equals $100,000 \mathrm{~W}$, where $\mathrm{W}$ equals the weight in pounds and $\mathrm{I}$ equals the L3

total length in inches.

\section{Aquatic Invertebrates}

A standard square-foot bottom sampler was used to make quantitative and qualitative collections of invertebrates in the streams. The number and kind of organisms and volume per square foot were determined. Samples were taken before and after spraying. (Figure 5.) Five square-foot samples were taken at each permanently marked collection station. On the two streams studied intensively, stations were established above, within and below the spray boundary. Aquatic invertebrates were identified to order except the flies (Diptera) which were determined to family.

\section{INTENSTVE STREAM STUDIES}

Canyon Creek and Trapper Creek in the Pioneer Mountains on the Beaverhead National Forest were selected as the streams for intensive study. (Maps II and III.) These streams are typical for this area and both are tributaries of the Big Hole River. The mouths of both streams are at about 5,100 feet elevations, with study sections from 6,000 to 8,000 feet. During the summer months most of the water in these streams is diverted for irrigation below the forest boundary. Within the study areas the streams vary in width from 10 to 25 feet with maximum depths from six inches in riffles to four feet in pools. They flow through lodgepole pine and spruce timber in the upper study sections, with an occasional open park; willow, birch and alder brush are found along the banks in the lower sections. (Figure 1.) Fir and lodgepole pine join the brush on the south bank with timber 200 to 300 feet back from the stream on the north side of the stream or south exposure. Pools and riffles are intermittent; bottoms are of gravel and rubble. Sections of increased gradient are rocky.

Streamflow and velocity were measured with a stream-depth and velocity gauge. Flow (cubic feet per second) and velocity (feet per second) were obtained for each station on the two streams as shown in tables 1 and 2 . Flow and velocity decreased as the season advanced. Water for irrigation was diverted above the lower station on both streams. This loss was reflected in the readings at these stations when water was being used. Flows on Canyon Creek ranged from about 80 cubic feet per second in midJune to six in mid-August. The normal summer flow averaged about 25 cubic feet per second. The smaller stream, Trapper Creek, had flows that ranged from about 40 cubic feet per second to five. The normal flow averaged about 15 cubic feet per second. Part of the water was diverted for irrigation above the lower station on both streams. 


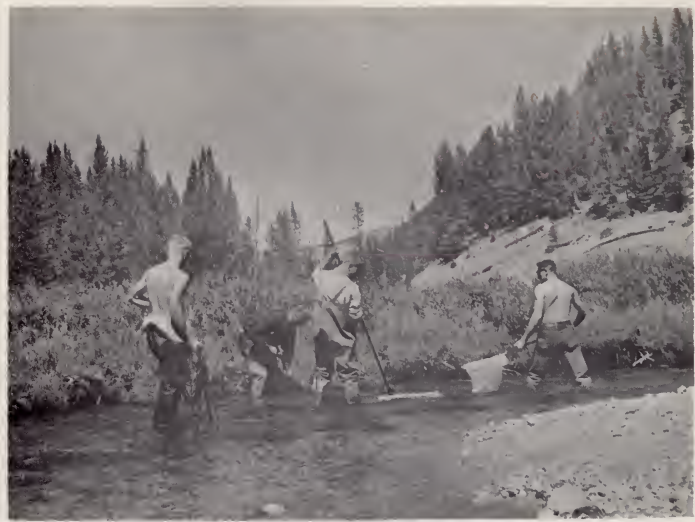

Figure 1. Fish shocking crew working station 2 on Canyon Creek.

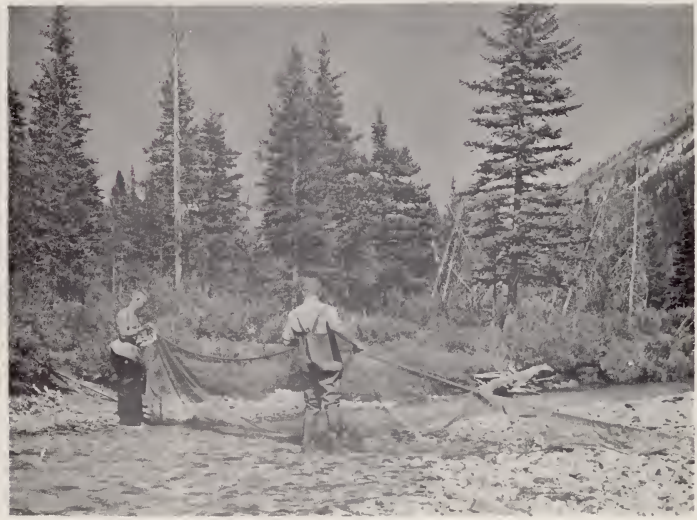

F1gure 2. Installation of block net before starting shocking 


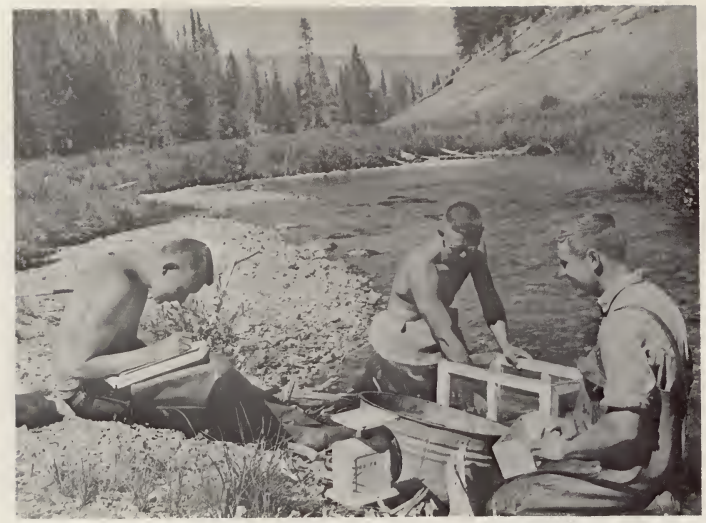

Figure 3. Weighing and measuring trout taken by shocking.

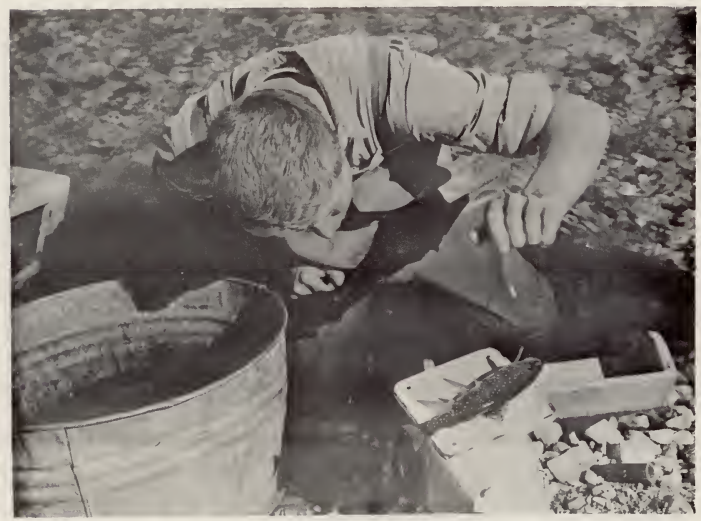

Figure 4. Weighing eastern brook trout. 


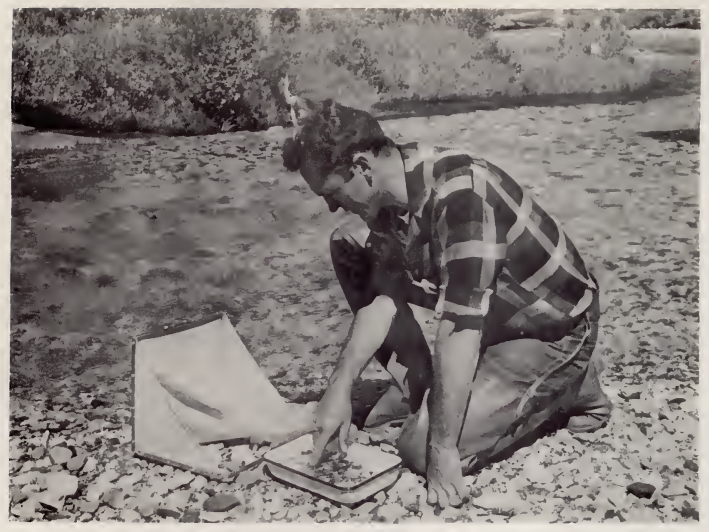

F1gure 5. Square-foot bottom sampler with contents in enamel pan for segregation--Canyon Creek.

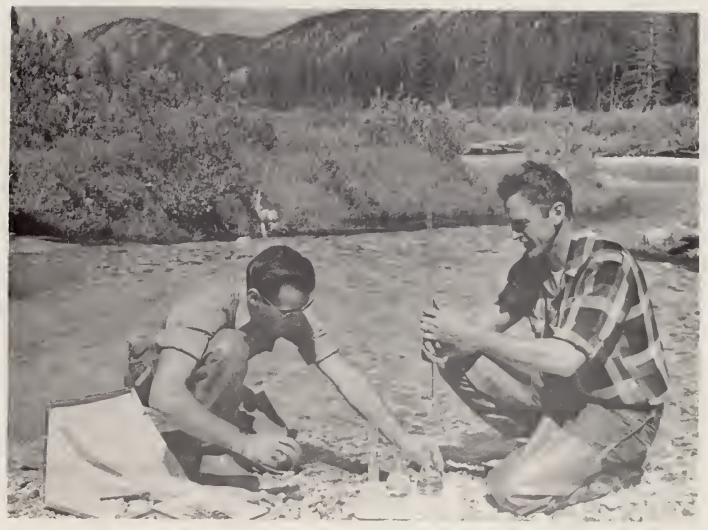

Figure 6. Testing water alkalinity--Canyon Creek. 


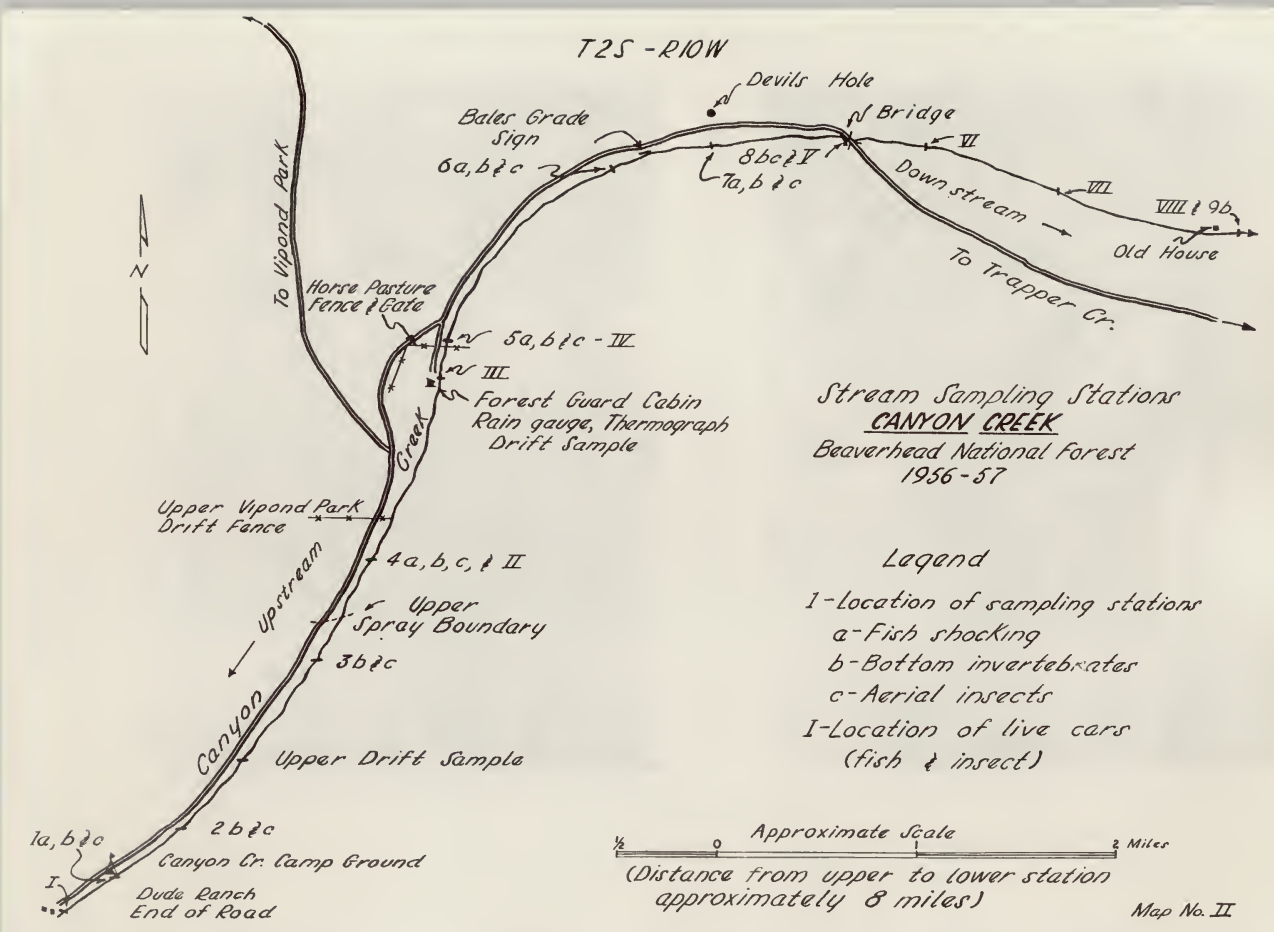




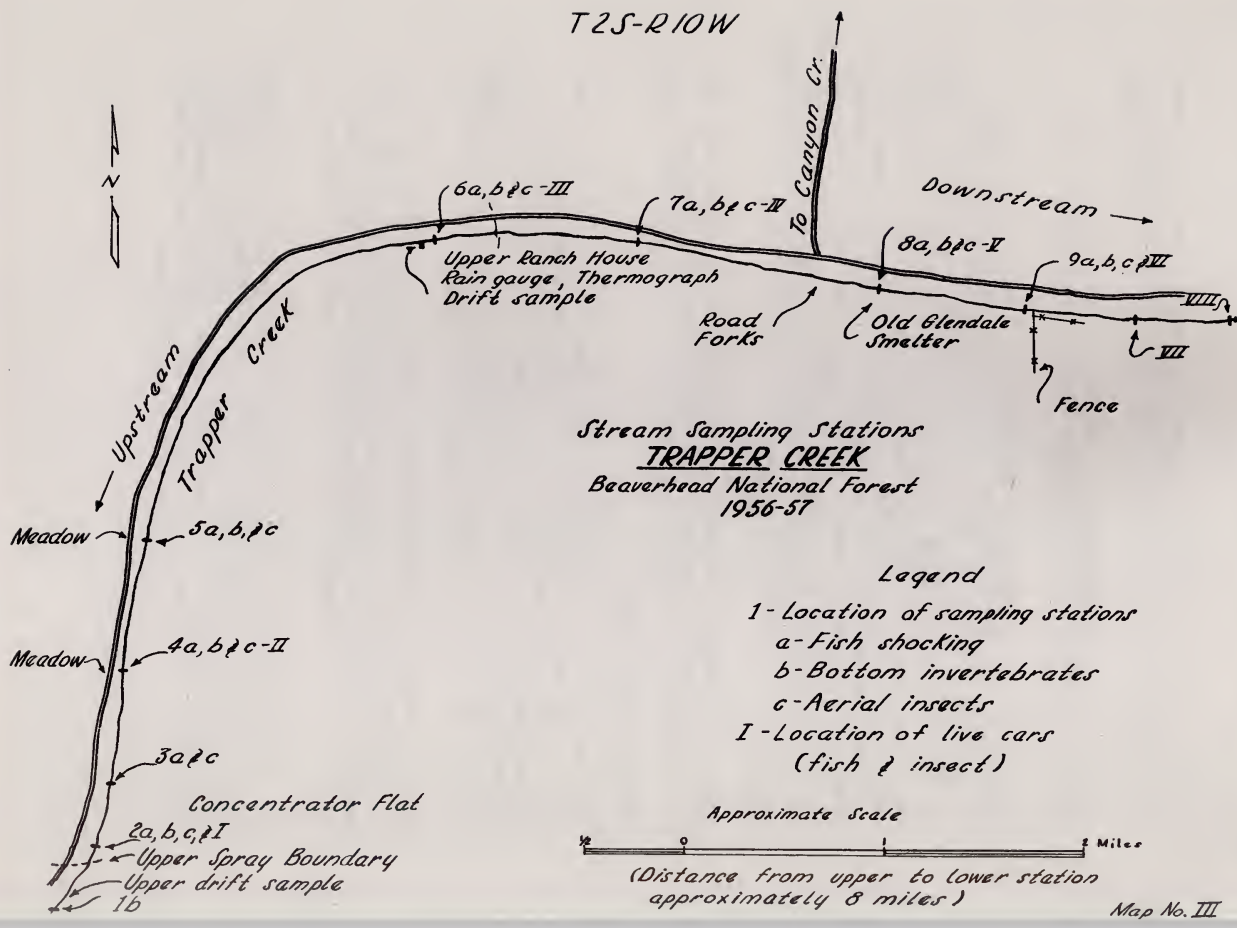


The pH values were determined by using a colorimetric comparator. Readings (Tables 1 and 2) for the two streams show that the hydrogen-ion concentrations are within the range favorable for fish and aquatic insects.

The methyl orange alkalinity was determined by using standard methods. (Figure 6.) Water in both streams was considered as moderately soft. (Tables 1 and 2.)

Daily maximum and minimum water temperatures were obtained by using a thermograph. One thermograph was located at the guard cabin on Canyon Creek and the other at the upper ranch house on Trapper Creek. (Maps II and III.) The average daily temperature fluctuation was 4 degrees Fahrenheit for Trapper Creek and 9 degrees Fahrenheit for Canyon Creek. According to the character and cover of the two streams, it would be expected that Trapper Creek would have the greater daily fluctuation. Temperatures on Canyon Creek ranged from a minimum of $40^{\circ} \mathrm{F}$. on June 25 , to a maximum of $65^{\circ} \mathrm{F}$. on July 25. On Trapper Creek, temperatures ranged from a minimum of $45^{\circ} \mathrm{F}$. on June 20 to a maximum of $58^{\circ} \mathrm{F}$. on July 25. More stable daily and seasonal temperatures on Trapper Creek indicate it was influenced by springs. Both streams had suitable water temperatures for trout. (Table 3.)

Standard rain gauges were located at the guard cabin on Canyon Creek and at the upper ranch on Trapper Creek. These gauges were installed to measure rainfall from heavy storms. No weather records were taken in 1957.

Analysis of DDT in Water

Five water samples of one gallon each were taken at the lower end of the spray area on Canyon Creek in 1956 for the purpose of determining the amount of DDT in the water after spraying and after a heavy rain.

Separate samples for the determination of turbidity were taken on both streams (Table 4). The water in both streams was very clear, having only 0.09 parts per million of suspended material in the Canyon Creek sample and 1.0 parts per million in the Trapper Creek sample.

The first water sample taken immediately after spraying contained 0.10 parts per million of DDT. There was 0.33 parts per million of DDT onehalf hour after spraying; 27 hours later the amount of DDT was not measurable. It is quite probable that the 0.33 parts per million was near the peak of the amount of DDT at the point where the samples were taken.

The oil used as a diluent could be seen in the eddies along both streams for several days after spraying. The mortality and morbidity in bottom organisms suggest that DDT drops to the bottom rapidly when the water is agitated in riffle areas. In less than 27 kours there was no measurable amount of DDT in the water. The effect on the insects in the live cars indicates that the DDT is diluted as it.moves downstream. 
It was planned that water samples would be taken in the streams after storms to determine the amount of DJT leaching into the streams. The only heavy rainfall after spraying came on July 3, when 1.2 inches of rain fell, but no neasurable amount of DDT was found in this sample (Table 4). The rain apparently did not cause leaching of DDT into the stream. I/ The precipitation fell within a 12-hour period and the water sample was taken one hour after the rain stopped. This collection was near the peak of the increased streamflow due to this heavy rain.

\section{Trout Population Index and Condition Factor}

Tables 5 and 6 show the results of shocking on Canyon Creek and Trapper Creek. Data obtained from prespray shocking (June 1956) are not included because high water prevented efficient recovery of fish. Greater numbers were taken on both-streams during the july 1956 shocking than on the prespray sampling.

Small brook trout were predominant in the populations of both streams. Rainbow trout, cutthroat trout and rainbow and cutthroat hybrids were grouped together because of small semple size. Aboidt the same number of trout were taken on both streams in August 1956 as in July 1956. The total number of trout in sprayed sections in August 1956 was 140 for Canyon Creek and 324 for Trapper Creek. In August 1957, the numbers were 105 and 289 respectiveiy. There is a decline in numbers for both streams. This decrease may or may not have been the result of nornal population fluctuations.

Fish smaller than three inches could not be captured efficiently and were not recorded in 1956 sampling. In 1957, greater effort was made to recover these fish but they are not included in population index numbers. Twelve brook trout and rainbow less than three inches were captured on Canyon Creek in 1957. Numerous yearling brook trout were collected from Trapper Creek in 1.957 (Figure 7) showing a survival of young-of-the-year fish of 1956.

Condition factors between July 1956 and Aigust 1956 decreased for Canyon Creek and remained about the same for Trapper Creek. In 1957, condition factors were higher than in 1956 for both streams.

\section{Fish Live Cars}

One hundred and sixty-two wild trout taken by shocking from Canyon and Trapper Creeks were held in cages or live cars (eight in each stream) during spraying and for three days after spraying. (Tables 7 and 8.) The fish were collected and held 24 hours before placing in the individual cages to eliminate any loss from shocking and handiing. (Figures 8 and 9.) The trout were placed in the cars 48 hours hefore spraying, for the same reason. Four fish were lost; two from the shocking and handling operation

I/ In 1957 water samples were collected from the Ruby River after . 34 and .85 inch rainfalls. One sample was collected 12 days after the initial spraying on July 7, while tice oticer was taken a month after the entire drainage had been sprayed. There was no measurable DDT in the samples. 
and two from damage from rocks in the cages. Curious fishermen apparently moved the cars, rolling the rocks and killing two trout. As the tables indicate, no fish were lost in the live cars on spray day or during the three days following spraying.

Some of the trout in live cars ate considerable amounts of the dead and dying insects that washed into the cages following spraying. An abundance of these insects was available to the trout in all of the cars except those in unsprayed sections, but many of the fish opened had empty stomachs, indicating that the trout in live cars were not feeding. Free trout in both streams gorged themselves on these dead and dying insects. Some of the fish stomachs were so distended that insects could be identified through the stomach wall.

There was a noticeable difference between rainbow and eastern brook trout behavior in the cars. The brook trout were quieter and fed more consistently on the insects coming into the cars. At the end of the holding period all trout were in excellent physical condition, but the brook trout were noticeably fatter.

\section{Analysis of Trout Tissues}

The analysis of trout tissue for DDT is shown in table 9. In general, relatively low values were obtained in the tissues analyzed. It seems probable that DDT tends to accumulate primarily in the visceral fat, secondarily in the pyloric caeca and occasionally in the kidney, probably during detoxification. The visceral fat was the most common location for DDT storage. DDT accumulation in this tissue varied from 0.01 microgram to approximately four micrograms per milligram of dry tissue.

The amounts of DDT were so variable in 1956 samples taken the same day and at the same station and throughout the season, that no conclusions can be made.

On November 7, 1957, six live eastern brook trout were taken from station 8 on Canyon Creek and six from station 7 on Trapper Creek. These samples contained 3.3 p.p.m. and 0.3 p.p.m. of DDT respectively, 16 months after spraying. If

Trout Stomach Food Analysis

Trout stomach samples were taken at intervals during the sumner of the 1956 season in spray areas to determine diets. The trout were always able to obtain food from terrestrial insects or fly larvae during the summer.

Stomach samples were also taken from fish held in the live cars. Table 10 shows the results of the analyses of these samples. As previously

I/ Chemical analyses made by Chemistry Department, Montana State College, Bozeman, Montana. 


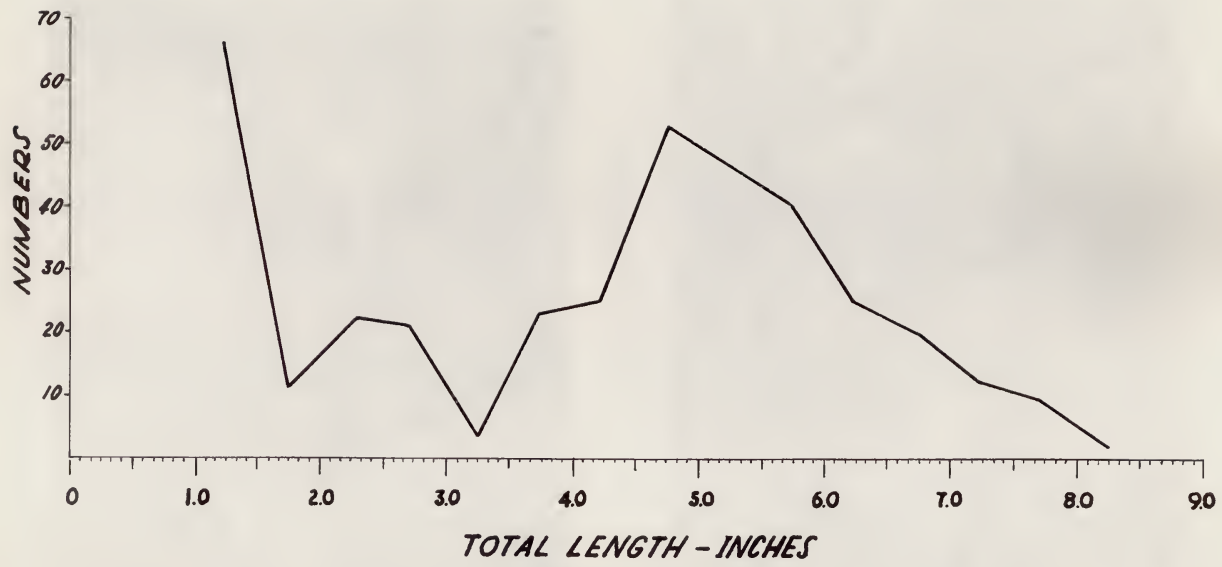

Fig. 7 Length frequency for 382 eastern brook trout collected by shocking on Trapper Creek, August 7-9, 1957 


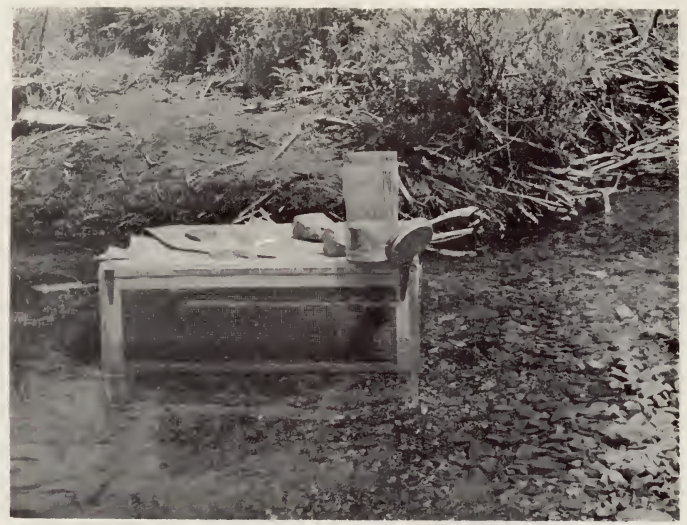

Figure 8. Fish and insect live cars.

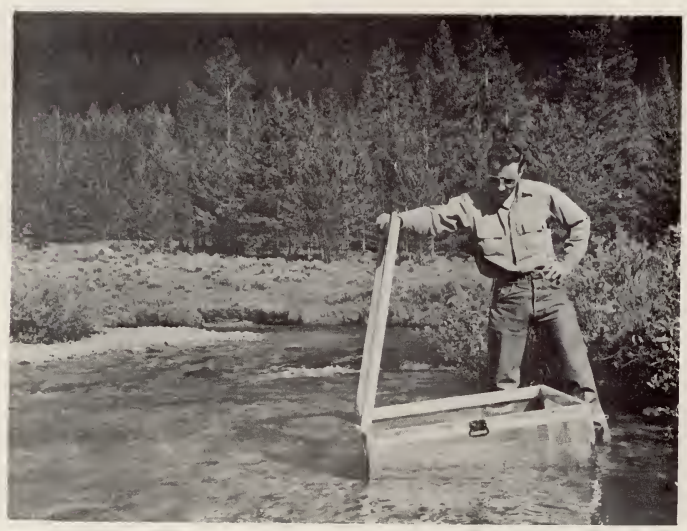

Figure 9. Fish live car at station 2--Canyon Creek. 
mentioned, stomachs from some of the trout held in the live cars were empty, and brook trout fed better under these abnormal conditions than did the rainbow trout. Quantities of aquatic insects killed by the spray were available to the fish in all of the live cars within spray areas. Live car number I, located at the control station on Canyon Creek, contained an abundance of live larvae; again, the brook trout were the best feeders under these conditions.

Following the period when dead aquatic insects were plentiful, it was expected that within the sprayed areas where the bottom organisms had been depleted, trout would be hungry and easily caught. Actually, there was no time during the season when fish could be caught easily in either stream.

There is no indication from the data collected during the 1956 season that trout were directly affected by the spray.

No stomach samples were taken in 1957.

\section{Drift Samples}

A plankton towing net of zero mesh was used to take drift samples of stream insects as shown in figures 10 and 11 . Under normal conditions small quantities of nymphs are continually being carried downstream in the water. However, within minutes after DDT spray reaches the water, the bottom organisms lose their hold on the rocks, come to the surface in great numbers and float downstream. By leaving the net in the water five minutes, an adequate sample was obtained. (Figure 12.) The measurement of these floating aquatic invertebrates aids in the evaluation of results from bottom sampling, as it is difficult to differentiate between big hatches of aquatic insects and loss due to the effect of DDT spray.

All drift samples were taken at one location on each stream throughout the season, except as indicated in tables 11 and 12 . The 5-minute sample of $1.5 \mathrm{cc}$. taken on july 1 before spray day in Canyon Creek (Table 1I) was predominantly early instar mayfly nymphs. A similar sample on Trapper Creek of $0.2 \mathrm{cc}$. was composed of very small mayfly and stonefly nymphs. (Table 12.) The samples taken on July 1 before spray day, and those following (until July 9), indicate differences in volume of bottom fauna in the two streams. Canyon Creek is a richer trout food producing stream than Trapper Creek. This difference is also borne out in the bottom sample sumaries. (Tabies 13 and 14.)

All of the insects taken in the net from 6:30 a.m. July 2 (spray day) to July 6 were dead and dying insects affected by the spray. A few minutes after the spray hit the water it began to affect the bottom organisms even though an oil slick remained on top, indicating that some DDT reached the bottom. On the spray day the first drift sample on Canyon Creek was taken one hour after the spray hit the water $(6: 30 \mathrm{a.m.})$. This 5-minute 


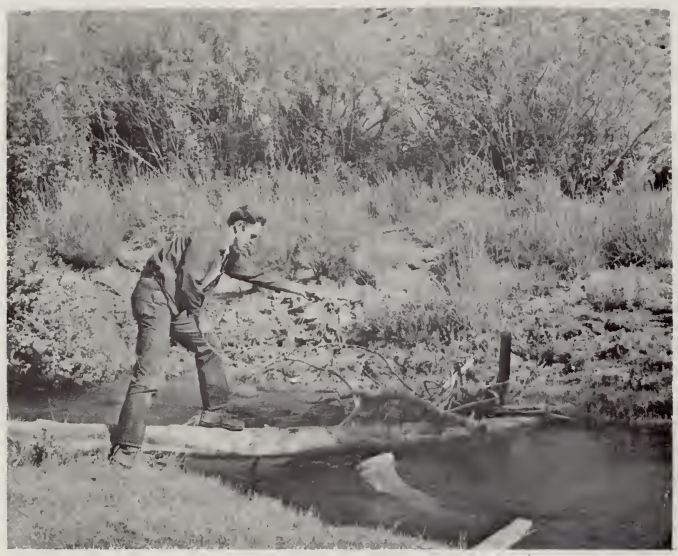

Figure 10. Taking drift sample. 


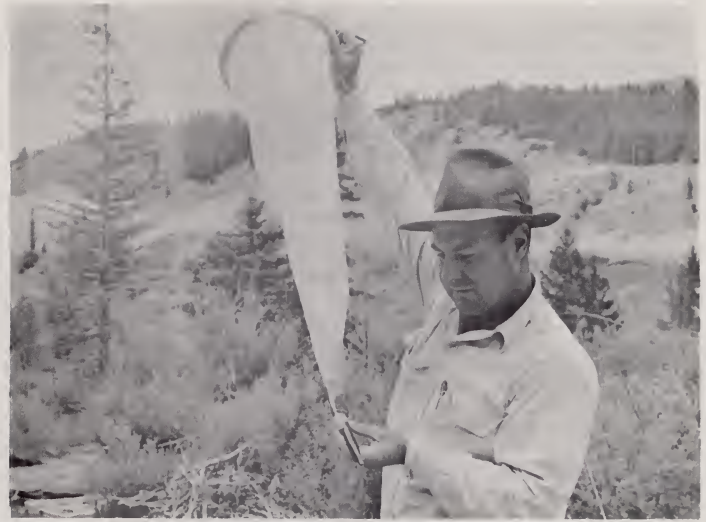

Figure 11. Plankton net with contents from 5-minute drift sample--Canyon Creek.

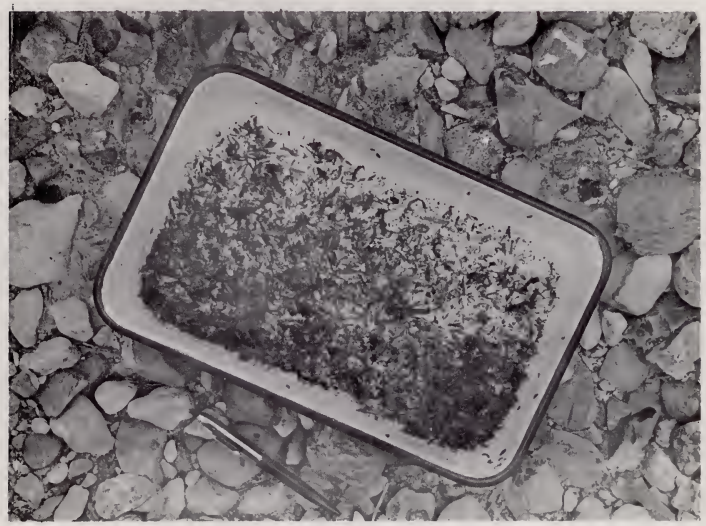

Figure 12. Contents of 5-minute drift sample on Canyon Creek several days after spraying. 
sample contained $150 \mathrm{cc}$. of dead and dying insects, predominantly immature stoneflies, mayflies, and caddisflies. By $6: 45 \mathrm{p} . \mathrm{m}$. the volume had decreased to $55 \mathrm{cc}$. and by morning on July 3 it had decreased to $1.5 \mathrm{cc}$. No dead or affected nymphs of aquatic insects were taken in the net five days after spraying (July 6). The effect on Trapper Creek was similar except that the quantity of nymphs was less, due to a natural lower population of aquatic bottom faura (Tables 13 and 14).

The last samples taken on Canyon Creek in September and October show a slight increase in the volume of mayflies and stoneflies being carried down the stream, especially at the control station. This same increase does not show up in the Trapper Creek drift samples, but data for both streams agree on the negligible trace amounts coming downstream during the period July 9 to September 19. There was a small temporary increase (average $0.2 \mathrm{ec}$ ) ) in the fiy populations on Trapper Creek the latter part of July and forepart of August. The lack of increase in the September and October samples on this stream could be significant. This could be partially cue to the lower aquatic insect population.

Drift samples taken above the spray area on both streams on July 2 and July 4 (Tables 17 and 12) were prespray samples of small live aquatic insects. The samples taken on July 18 in Canyon Creek, both inside and outside of the spray area, indicate that there are times when very limited numbers of small nymphs are being carried downstream. This may be expected because the number being carried by the water is partly dependent upon hatching periods. On October 19 the sample at the cabin station on Canyon Creek, which is within the spray area, contained $0.2 \mathrm{cc}$. (perhaps newly hat,ched) and the next day at the upper station outside the spray area a sample had $2.9 \mathrm{cc}$. On October 23 the samples taken at both stations were more nearly equal, but one was predominently mayflies and the other stoneflies.

\section{Stream Bottom Samples}

Square-foot bottom samples were taken throughout the 1956 and 1957 seasons at nine stations on each stream with a Surber stream-bottom sampler (Surber, 1937). Five separate square-foot samples were taken at each station and the volume per square foot shown in tables 11 and 12 is the average of tine 5 samples. The data in these tables are, therefore, based on a series of samples taken on 8 different dates at each of 9 stations. Figure 5 shows equipment used, the cover plate of this publication the method of taking samples, and figure 15 the contents of a 1-square-foot sample from Canyon Creek.

The first bottom samples after the spray day were not taken until most of the insects first affected by the spray had floated downstream. This collecting date (July 9) was determined by drift sampling (Tables 13 and 14). 
VOLUMES OF STREAM BOTTOM INVERTEBRATES CANYON CREEK

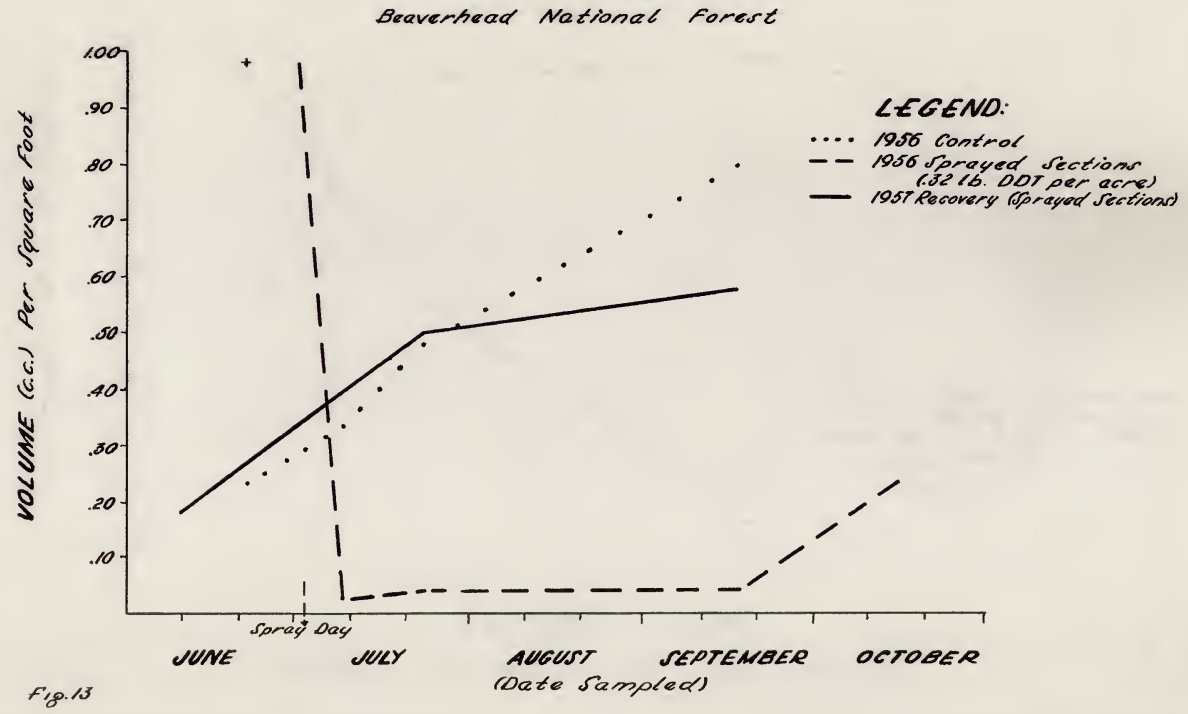




\section{VOLUMES OF STREAM BOTTOM INVERTEBRATES}

\section{TRAPPER CREEK}

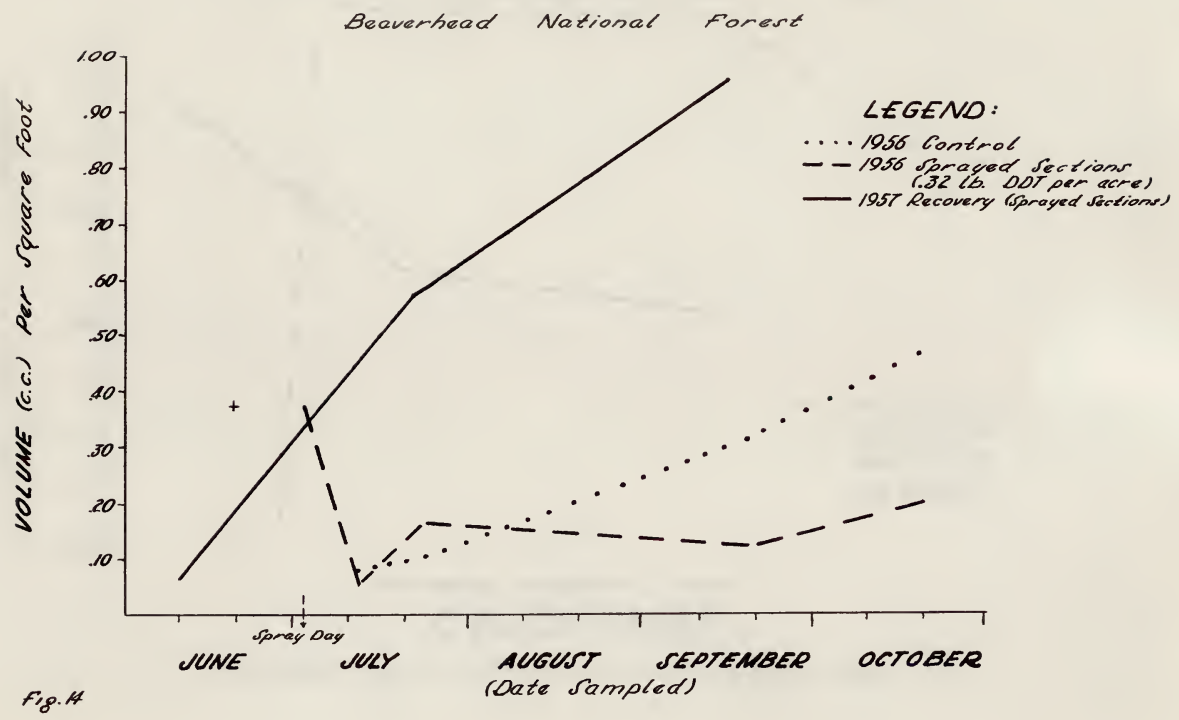




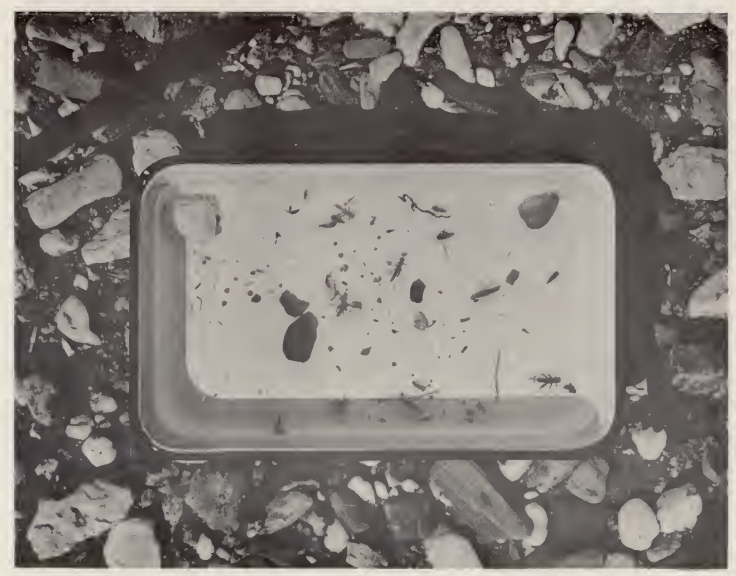

Figure 15. Contents of a square-foot bottom sample. Stoneflies and mayflies--Canyon Creek. 
Comparisons of volume of predominant invertebrates before and after spraying on Canyon Creek and Trapper Creek in 1956 . Lidicated a material reduction in bottom organisms caused by the DDT aerial spray. The last 1956 bottom samples were taker in October on both streams and, as shown in tables 11 and 12, there was an increase in volume of aquatic insects in the sprayed areas. However, by October, the average volume of samples taken at the sprayed stations on Canyon Creek was only one-fourth of the average volume before spraying. Sampies from the unsprayed stations showed a fourfold increase during the same period. (Figures 13 and 14.)

Additional sampling was done during the 1957 season to learn more about the rate of recovery and the length of time required to reach a near normal aquatic bottom fauna population on both streams. The term "near normal" means the recovery of the predominant forms which produce the bulk of the food for trout in these streams.

Both Canyon Creek and Trapper Creek were resampled in June, July and September 1957. Trapper Creek made a near normal recovery by September 16, 1957. On this date the volume of insects had increased eightfold over a comparable sample taken in September 1956. The September 1957 volume was also greater than the 1956 prespray volume.

On Canyon Creek the September 1957 volume of insects in sprayed sections were considerably greater than the September 1956 volume. Control stations showea greater volume in the fall (1956-57) than in the prespray spring samples. However, in the spray area, fall samples (1957) contained less insects than prespray spring samples. This would indicate that recovery was not complete on this stream.

\section{Aquatic Insect Iive Cars}

Live cars containing aquatic insects were placed near each of the live cars containing fisk before spraying (Figure 8). Bottom fauna, predominantly imature stages of stoneflies, mayflies, and caddisflies, were placed with stones in each live car. The effect of the DDT spray is shown in table 15. Mortaities agree with those from drift and square-foot bottom samples. Insects in the live car at the control station on Canyon Creek were unaffected. Insects in the live cars within the spray area were all affected and were dead or dying after 24 hours. The effect upon insects in live cars bolow the spray area decreased according to the distance below the spray area in Trapper Creek. Insects appeared normal at $1 \frac{1}{2}$ miles downstream, indicating that at this distance the amount of DDT in the water was so diluted that it did not affect the insects in the cages. This fact is further substantiated by the bottom samples taken at these stations. (Tables 13 and 14.)

\section{Sweep-net Collections}

A standard insect net was used to collect aerial insects near the streambanks before spraying and at intervals during the season after spraying 
at 16 stations on the two streams in 1956. These stations, with two exceptions, were near the bottom sample stations (Maps II and III). Five sweeps of the net were made for each sample and twenty samples were taken at each station. The twenty sweep-net samples were taken from bushes on both sides of the stream adjacent to the bottom sampling areas. Only adults of aquatic bottom insects were tallied. See tables 16 and 17. Very few terrestrial insects were taken.

The reduction in adult aquatic insects appears to have been more drastic on Canyon Creek than on Trapper Creek. Effect on adults was, however, very definite on both streams. Midges (Tendipedidae) increased greatly, beginning with the second samples after spraying. This is a much faster buildup in population than is shown by bottom samples or drift samples. The lack of correlation between samples of aquatic adults and bottom samples may be due to the gelatinous covering of the eggs of flies which may protect them from the DDT spray. A good percentage of the flies occurring in the later bottom samples were midge larvae, but the midges in the earlier aerial samples may have belonged to a different subfamily or genus. The figures shown for the samples of adult aquatic insects are based on numbers; bottom sample figures are given in volume. This accounts for some of the difference, since some dipterous larvae were found in bottom samples throughout the season, but midges were too small to account for much volume. In numbers in some of the sprayed sections they were the predominant insects on the stream bottom after spraying, indicating a very short life cycle, protection from the DDT in the egg or early larval stage, or migration from unsprayed areas.

No sweep-net collections were made in 1957.

EXTENSIVE STREAM STUDIES

\section{$\underline{\text { Aquatic Insects }}$}

A prespray and a post spray collection of bottom samples was made on eleven streams during 1956 (Table 18). The data substantiated findings on Canyon Creek and Trapper Creek. The DDT spray caused a marked loss of aquatic insects in sprayed stations.

Five of these streams were selected for study in 1957 in order to observe any delayed effects and the recovery rate of bottom ar ganisms. (Table 18.) Four of these streams had an abundance of aquatic insect life and loss following spraying was severe. The fifth stream (Rattlesnake Creek) was selected to observe effects considerably below the spray area. Since control stations were lacking and normal insect abundance for mid-summer was not known, the degree of recovery could not be ascertained. However, on four of these streams, Rattlesnake Creek, Beaver Creek, North Fork Smith River and North Fork Musselshell River, insect quantities were much greater in 1957 than following spraying in 1956. The qualitative recovery could not be determined by the methods used. 
Five study sections were established on the fifth stream (Sheep Creek) in 1956. The upper three sections were in the spray area and the lower two were several miles below the spray boundary. The average volume per square foot of aquatic insects for the five stations decreased from $3.37 \mathrm{cc}$. before spraying to $0.88 \mathrm{cc}$. about one month after spraying (August 2, 1956). On August 14, 1957, the average volume per square foot for the lower stations was $0.66 \mathrm{cc}$, but for the upper three stations it amounted to only $0.02 \mathrm{cc}$. Only a trace of aquatic organisms was found in sprayed stations about 15 months after spraying.

\section{Fish Populations}

Results of fish population studies on these eleven streams during 1956 were similar to those for Canyon Creek and Trapper Creek. High water prevented efficient prespray sampling. The only decline in numbers of fish between the prespray and post spray sampling of 1956 occurred on one study section of the Musselshell River, where brook trout numbers decreased from 235 to 134 or about 43 percent.

Fish population indices for 1957 were obtained for the same 5 streams selected for observation of insect recovery (Table 19). On 3 of these streams, Rattlesnake Creek, Beaver Creek and North Fork Smith River, the numbers of fish collected in 1957 equaled or exceeded those taken following spraying in 1956.

On the North Fork Musselshell River, the total number of brook trout taken from the two sections on July 31, 1956 was 253, while on August 15, 1957, only 75 were recovered. This decline, about 70 percent, is more than would be expected in normal population fluctuations. Although the number of trout 3 inches and longer decreased considerably, numerous living 1 and 2 -inch fish were observed.

On Sheep Creek, the number of fish collected from the lower two sections (below the spray area) in August 1956, were 84 rainbow and cutthroat trout and 32 whitefish. In 1957 there were 87 and 66, respectively. In the upper 3 sections (In the spray area) 60 brook trout, 26 rainbow and cutthroat trout, and 94 whitefish were taken in August 1956. These numbered 5, 10 and 14, respectively, in 1957. While the numbers of game fish remained about the same between 1956 and 1957 in the lower sections, numbers in the upper sections decreased about 84 percent. Many sculpins were collected in the upper sections in August 1956, but not one was observed in 1957 . 
Adams, Lowell, Mitchell Hanavan, Neil W. Hosley, and David W. Johnson. 1949 The effects on fish, birds and mammals of DDT used in the control of forest insects in Idaho and Wyoming. Jour. Wildlife Mgmt. 13(3): 245-254.

Balch, R. E., F. E. Webb, and J. J. Fettes.

1956 The use of aircraft in forest insect control. Forestry Abstracts Leading Article Series No. 23. For. Biol. Div., Dept. of Agric., Canada. Ottawa. Reprinted from Forestry Abstracts, Vol. 16, No. 4, 1955, and Vol. 17, Nos. 1 and 2, 1956, $31 \mathrm{pp}$.

Brown, A. W. A.

1951 Insect control by chemicals. John Wiley \& Sons, New York, $817 \mathrm{pp}$.

Carlander, Kenneth D.

1950 Handbook of freshwater fishery biology. Dubuque, Wm. C.

Brown Co., $281 \mathrm{pp}$.

Coburn, Don R. and Ray Treichler.

1946 Experiments on toxicity of DDT to wildlife. Jour. Wildlife Mgmt. 10(3): 208-216.

Cope, 0. B. The effect of mosquito insecticides on wildlife. Proc. 1949 17th Ann. Conf. Calif. Mosq. Control Assoc., pp 53-55.

, C. M. Gjullin, and A. Storm. Effects of some insecticides on trout and salmon in Alaska, with reference to blackfly control. Trans. Amer. Fish. Soc. $77: 160-177$.

Toxicities and tolerances of new insecticides in relation 1948 to wildlife and fish. Proc. 16th Ann. Conf. Calif. Mosq. Control Assoc., pp 1-6.

Cottam, Clarence C.

1948 The effects of new insecticides on fish and wildlife. Jour. Econ. Ent., pp 1-14.

1947 Effects of DDT and other new insecticides on wildlife. Jour. Econ. Ent., pp 1-12.

and E. Higgins.

1946 DDT: 'Its effect on fish and wildlife. Fish and Wildlife Service, Circ. 11, pp 1-14. 
Douderoff, P., M. Katz, and C. M. Tarzwell.

1953 Toxicity of some organic insecticides to fish. Sewage and Industrial Wastes. 25(7): 840-844.

Ellis, M. M., B. A. Westfall, and M. D. Ellis.

1946 Determination of water quality. Fish and Wildife Serv., Res. Rep. 9, pp 1-122.

Fielding, J. R. and W. P. Baldwin

1955 Effect of some new insecticides on fish and wildlife. N. C. Agric. Expt. Sta. Pesticide Hdbk., pp 1-15.

Gjullin, C. M., O. B. Cope, B. F. Quisenberry, and F. R. DuChanois. The effect of some insecticides on blackfly larvae in Alaskan streams. Jour. Econ. Ent. 42(1): 100-105.

Hoffmann, C. H. and J. P. Drooz.

1953 Effects of a C-47 airplane application of DDT on fishfood organisms in two Pennsylvania watersheds. Amer. Midland Nat. 50(1): 172-188.

and J. P. Linduska.

1949 Some considerations of the biological effects of DDT.

Sci. Mo., 69: 104-114.

and E. W. Surber

1949 Effects of an aerial application of DDT on fish and fishfood organisms in two Pennsylvania watersheds. Prog.

Fish-Cult. 11(4): 203-211.

1949 Effects of feeding DDT-sprayed insects to fresh-water fish. Fish and Wildlife Serv., Spec. Sci. Rept.

Fisheries No. 3, pp 1-9.

and E. P. Merkel.

1948 Fluctuations in insect populations associated with aerial applications of DDT to forests. Jour. Econ. Ent., 41(3): $\quad 464-473$

, H. K. Townes, R. I. Sailer, and H. H. Swift.

1946 Field studies of the effect of DDT on aquatic insects.

U.S.D.A., Agr. Res. Adm., Bur. Ent and P. Q., E-702.

Mimeo., pp 1-20.

Kerswill, C. J. and P. F. Elson.

1955 Preliminary observations on effects of 1954 DDT spraying in Mirimichi salmon stocks. Prog. Repts., Atlantic Coast Stations, Fish. Res. Bd. of Canada, Issue No. 62, pp 17-24. 
Linduska, J. P. and E. W. Surber.

1949 Effects of DDT and other insecticides on fish and wildlife. Summary of investigations during 1947. Fish and Wildlife Serv., Cir. 15, pp 1-19.

Needham, Paul R.

1938 Trout streams. Ithaca, Comstock, 233 pp.

Pennak, Robert $W$. 1953

Fresh-water invertebrates of the United States. New York, Ronald Press, 769 pp.

Rudd, Robert L. and Richard E. Genelly. 1956

Pesticides: Their use and toxicity in relation to wildlife. Calif. Dept. Fish and Game, Game Bul. 7, pp. 1-209.

Scott, H. R. and F. A. MacDougall.

1952

Forest spraying and some effects of DDT. Dept. Lands and Forests, Ontario. Biol. Bul. No. 2, pp. 1-174.

Stefanich, Frank A.

1952

The population and movement of fish in Prickly Pear Creek, Montana. Trans. Amer. Fish. Soc. 81:260-274.

Welch, Paul S. 1948

Limnological methods. New York, Mc-Graw-Hill. 381 pp. 



\section{APPENDIX}

Table 1 - Summary of streamflow measurements and water chemistry determinations, Canyon Creek, 1956.

Table 2 - Summary of streamflow measurements and water chemistry determinations, Trapper Creek, 1956.

Table 3 - Daily maximum and minimum water temperatures in degrees, Fahrenheit, Trapper and Canyon Creeks, 1956.

Table 4 - DDT content and turbidity of water from Canyon Creek and Trapper Creek, 1956.

Table 5 - Numbers of trout collected by shocking, Canyon Creek, 1956-1957.

Table 6 - Numbers of trout collected by shocking, Trapper Creek, 1956-1957.

Table 7 - Survival of trout in live cars, Canyon Creek, 1956.

Table 8 - Survival of trout in live cars, Trapper Creek, 1956.

Table 9 - Analysis of tissues from trout exposed to DDT, 1956.

Table 10 - Summary of the volumes of food in trout stomachs from Canyon and Trapper Creeks and from live cars held in these streams, 1956.

Table 11 - Volumes of insects collected in 5-minute drift samples, Canyon Creek, 1956.

Table 12 - Volumes of insects collected in 5-minute drift samples, Trapper Creek, 1956.

Table 13 - Volume per square foot of predominant stream bottom invertebrates collected in Canyon Creek, 1956-1957.

Table 14 - Volume per square foot of predominant stream bottom invertebrates collected in Trapper Creek, 1956-1957.

Table 15 - Summary of mortality of insects and fish in live cars, Canyon and Trapper Creeks.

Table 16 - Numbers of adult aquatic insects collected by sweep net at Canyon Creek, 1956.

Table 17 - Numbers of adult aquatic insects collected by sweep net at Trapper Creek, 1956.

Table 18 - Volumes (cc.) per square foot of stream invertebrates collected in bottom samples, Helena, Lewis \& Clark and Beaverhead National Forests, 1956-1957.

Table 19 - Numbers of game fish collected in five streams by shocking, 1956-1957. 
Table 1 - Simnary of streamflow measurements and water chemistry

\begin{tabular}{lllccc}
\hline Station & Date & $\begin{array}{c}\text { Flow } \\
\text { (cfs) }\end{array}$ & $\begin{array}{c}\text { Velocity } \\
\text { (f.s.) }\end{array}$ & pH & $\begin{array}{c}\text { M.0. } \\
\text { Alkalinity (p.p.m.) }\end{array}$ \\
\hline 7 & $6 / 22$ & 42 & $3-5$ & 8.3 & 52 \\
7 & $7 / 9$ & 39 & $3-4$ & 8.1 & 62 \\
1 & $7 / 23$ & 25.5 & $2-3$ & 8.3 & 70 \\
1 & $8 / 20$ & 11 & $1-3$ & 8.3 & 96 \\
& & & & & \\
2 & $6 / 23$ & 40 & $3-4$ & 8.3 & 54 \\
2 & $7 / 10$ & 39 & $3-4$ & 8.1 & 62 \\
2 & $7 / 23$ & 25 & $2-3$ & 8.5 & 70 \\
2 & $8 / 20$ & 11 & $1-3$ & 8.3 & 96 \\
& & & & & \\
3 & $6 / 23$ & 42 & $3-4$ & 8.3 & 60 \\
3 & $7 / 10$ & 28.2 & $2-4$ & 8.2 & 68 \\
3 & $7 / 23$ & 25 & $2-4$ & 8.5 & 80 \\
3 & $8 / 20$ & 12.7 & $2-3$ & 8.3 & 100 \\
4 & $6 / 23$ & 50 & $3-5$ & 8.3 & 66 \\
4 & $7 / 10$ & 28 & $3-4$ & 8.2 & 68 \\
4 & $7 / 23$ & 19 & $2-4$ & 8.5 & 79 \\
4 & $8 / 20$ & 12 & $2-3$ & 8.4 & 104 \\
& & & & & \\
5 & $6 / 18$ & 80 & $3-5$ & 8.1 & 60 \\
5 & $7 / 9$ & 36 & $3-4$ & 8.4 & 86 \\
5 & $7 / 23$ & 17 & $2-4$ & 8.6 & 88 \\
5 & $8 / 20$ & 12 & $2-3$ & 8.4 & 106 \\
6 & $6 / 19$ & 71 & $3-3$ & 8.1 & 60 \\
6 & $7 / 31$ & 31 & $2-4$ & 8.3 & 76 \\
6 & $7 / 24$ & 23 & $2-5$ & 8.5 & 93 \\
6 & $8 / 20$ & 6 & $1-3$ & 8.4 & 108 \\
7 & $6 / 19$ & 58 & $3-4$ & 8.1 & 60 \\
7 & $7 / 10$ & 27 & $3-5$ & 8.3 & 78 \\
7 & $7 / 24$ & 23 & $3-4$ & 8.5 & 95 \\
7 & $8 / 21$ & 6 & $2-3$ & 8.4 & 110 \\
8 & $6 / 19$ & 60 & $3-5$ & 8.1 & 60 \\
8 & $7 / 10$ & 28 & $3-4$ & 8.4 & 88 \\
8 & $7 / 24$ & 11 & $2-4$ & 8.6 & 104 \\
8 & $8 / 21$ & 6 & $2-3$ & 8.4 & 124 \\
\hline
\end{tabular}

Stations in order from upper to lower portion of stream. 
Table 2 - Summary of streamflow measurements and water chemistry determinations, Trapper Creek, 1956

\begin{tabular}{|c|c|c|c|c|c|}
\hline Station & Date & $\begin{array}{l}\text { Flow } \\
\text { (cfs) }\end{array}$ & $\begin{array}{l}\text { Velocity } \\
\text { (f.s.) }\end{array}$ & $\mathrm{pH}$ & $\begin{array}{c}\text { M.O. } \\
\text { A]kalinity (p.p.m.) }\end{array}$ \\
\hline 2 & $6 / 22$ & 37 & $3-5$ & 8.3 & 70 \\
\hline 2 & $7 / 11$ & 21 & $2-5$ & 8.2 & 70 \\
\hline 2 & $7 / 25$ & 10 & $2-4$ & 8.2 & 76 \\
\hline 2 & $8 / 22$ & 7 & $2-3$ & 8.3 & 90 \\
\hline 3 & 6/22 & 37 & $3-5$ & 8.3 & 70 \\
\hline 3 & $7 / 11$ & 21 & $2-5$ & 8.2 & 70 \\
\hline 3 & $7 / 25$ & 10 & $2-4$ & 8.2 & 76 \\
\hline 3 & $8 / 22$ & 6 & $2-3$ & 8.4 & 90 \\
\hline 4 & $6 / 21$ & 34 & $3-5$ & 8.3 & 75 \\
\hline 4 & $7 / 12$ & 24 & $2-4$ & 8.3 & 74 \\
\hline 4 & $7 / 25$ & 9 & $2-4$ & 8.3 & 82 \\
\hline 4 & $8 / 22$ & 8 & $2-3$ & 8.3 & 96 \\
\hline 5 & $6 / 21$ & -- & $3-5$ & 8.3 & \\
\hline 5 & $7 / 12$ & 18 & $2-3$ & 8.5 & 82 \\
\hline 5 & $7 / 25$ & 12 & $1-3$ & 8.4 & 92 \\
\hline 5 & $8 / 22$ & 7 & $1-2$ & 8.4 & 108 \\
\hline 6 & $6 / 20$ & 40 & $3-5$ & 8.3 & 88 \\
\hline 6 & $7 / 12$ & 22 & $3-5$ & $8 \cdot 3$ & 98 \\
\hline 6 & $7 / 25$ & 8 & $\begin{array}{l}2-4 \\
3-4\end{array}$ & 8.4 & 114 \\
\hline 0 & $8 / 21$ & 11 & $3-4$ & 8.3 & 134 \\
\hline 7 & $6 / 20$ & 40 & $3-4$ & 8.3 & 40 \\
\hline 7 & $7 / 12$ & 20 & $3-4$ & 8.4 & 106 \\
\hline 7 & $7 / 24$ & 12 & $2-3$ & 8.6 & 116 \\
\hline 7 & $8 / 21$ & 11 & 2 & 8.4 & 142 \\
\hline 8 & $6 / 20$ & -- & $3-4$ & 8.3 & 88 \\
\hline 8 & $7 / 13$ & 16 & $2-4$ & 8.5 & 108 \\
\hline 8 & $7 / 24$ & 9 & $2-4$ & 8.6 & 118 \\
\hline 8 & $8 / 21$ & 4 & $2-4$ & 8.4 & 140 \\
\hline 9 & $6 / 21$ & 38 & $4-5$ & 8.3 & 88 \\
\hline 9 & $7 / 13$ & 15 & $2-4$ & 8.5 & 110 \\
\hline 9 & $7 / 24$ & 10 & $2-4$ & 8.6 & 120 \\
\hline 9 & $8 / 21$ & 5 & $2-3$ & 8.5 & 134 \\
\hline
\end{tabular}

Stations in order from upper to lower portion of stream. 
Table 3 - Daily maximum and minimum water termperatures in degrees, Fahrenheit, Trapper and Canyon Creeks, 1956

\begin{tabular}{|c|c|c|c|c|c|c|c|c|c|}
\hline \multirow[b]{2}{*}{ Date } & \multicolumn{2}{|c|}{ Trapper $\mathrm{Cr}$. } & \multicolumn{2}{|c|}{ Canyon $\mathrm{Cr}$. } & \multirow[b]{2}{*}{ Date } & \multicolumn{2}{|c|}{ Trapper Cr. } & \multicolumn{2}{|c|}{ Canyon $\mathrm{Cr}$. } \\
\hline & $\begin{array}{c}\text { Max. } \\
\text { F. }\end{array}$ & $\begin{array}{c}\text { Min. } \\
\text { F. }\end{array}$ & $\begin{array}{c}\text { Max. } \\
\text { F. }\end{array}$ & $\begin{array}{c}\text { Min. } \\
\text { F. }\end{array}$ & & $\begin{array}{c}\text { Max. } \\
\text { F. }\end{array}$ & $\begin{array}{c}\text { Min. } \\
\text { F. }\end{array}$ & $\begin{array}{c}\text { Max. } \\
\text { F. }\end{array}$ & $\begin{array}{c}\text { Min. } \\
\text { F. }\end{array}$ \\
\hline$6 \longdiv { 2 0 }$ & 48 & 45 & -- & -- & $7 / 25$ & 58 & 53 & 65 & 51 \\
\hline $6 / 21$ & 49 & 45 & -- & -- & $7 / 26$ & 57 & 52 & 60 & 49 \\
\hline $6 / 22$ & 50 & 45 & -- & -- & $7 / 27$ & 55 & 53 & 59 & 52 \\
\hline $6 / 23$ & 50 & 48 & 51 & 47 & $7 / 28$ & 56 & 52 & 60 & 49 \\
\hline $6 / 24$ & 50 & 46 & 51 & 43 & $7 / 29$ & 57 & 53 & 61 & 51 \\
\hline $6 / 25$ & 50 & 45 & 53 & 41 & $7 / 30$ & 55 & 52 & 63 & 49 \\
\hline $6 / 26$ & 52 & 45 & 56 & 43 & $7 / 31$ & 54 & 52 & 56 & 51 \\
\hline $6 / 27$ & 54 & 48 & 56 & 44 & $8 / 1$ & 53 & 49 & 56 & 48 \\
\hline $6 / 28$ & 55 & 49 & 57 & 46 & $8 / 2$ & 54 & 51 & 55 & 48 \\
\hline $6 / 29$ & 54 & 49 & 56 & 45 & $8 / 3$ & 54 & 50 & 55 & 45 \\
\hline $6 / 30$ & 51 & 47 & 54 & 42 & $8 / 4$ & 53 & 50 & 51 & $4 \longdiv { 4 }$ \\
\hline $7 / 1$ & 51 & 48 & 52 & 43 & $8 / 5$ & 52 & 49 & 55 & 44 \\
\hline $7 / 2$ & 49 & 44 & 49 & 42 & $8 / 6$ & 52 & 50 & 54 & 49 \\
\hline $7 / 3$ & 49 & 44 & 51 & 41 & $8 / 7$ & 52 & 49 & 52 & 45 \\
\hline $7 / 4$ & 49 & 45 & 50 & 41 & $8 / 8$ & 54 & 48 & 53 & 42 \\
\hline $7 / 5$ & 50 & 46 & 53 & 41 & $8 / 9$ & 53 & 50 & 55 & 47 \\
\hline $7 / 6$ & 51 & 48 & 56 & 45 & $8 / 10$ & 51 & 49 & 54 & 46 \\
\hline $7 / 7$ & 53 & 48 & 57 & 44 & $8 / 11$ & 52 & 49 & 53 & 45 \\
\hline $7 / 8$ & 53 & 48 & 55 & 43 & $8 / 12$ & 53 & 48 & 50 & 45 \\
\hline $7 / 9$ & 55 & 50 & - & -- & $8 / 13$ & 50 & 49 & 56 & 46 \\
\hline $7 / 10$ & 55 & 51 & -- & -- & $8 / 14$ & 54 & 50 & 56 & 47 \\
\hline $7 / 11$ & 54 & 51 & 59 & 50 & $8 / 15$ & 54 & 52 & 57 & 50 \\
\hline $7 / 12$ & 54 & 49 & 59 & 47 & $8 / 16$ & 57 & 51 & 56 & 48 \\
\hline $7 / 13$ & 53 & 50 & 55 & 49 & $8 / 17$ & 56 & 51 & 55 & 47 \\
\hline $7 / 14$ & 54 & 49 & 52 & 47 & $8 / 18$ & 55 & 50 & 55 & 44 \\
\hline $7 / 15$ & 53 & 50 & - & $=$ & $8 / 19$ & 54 & 49 & 52 & 46 \\
\hline $7 / 16$ & 55 & 49 & 59 & 47 & $8 / 20$ & 54 & 50 & 51 & 46 \\
\hline $7 / 17$ & 55 & 50 & 59 & 47 & $8 / 21$ & 54 & 49 & - & -- \\
\hline $7 / 18$ & 55 & 50 & 59 & 47 & $8 / 22$ & 55 & 50 & 53 & 50 \\
\hline $7 / 19$ & 56 & 51 & 61 & 48 & $8 / 23$ & 54 & 50 & 52 & 50 \\
\hline $7 / 20$ & 55 & 52 & 61 & 49 & $8 / 24$ & 54 & 50 & 52 & 50 \\
\hline $7 / 21$ & 57 & 52 & 62 & 50 & $8 / 25$ & 53 & 49 & 52 & 48 \\
\hline $7 / 22$ & 57 & 52 & -- & - & $8 / 26$ & 52 & 49 & 52 & 49 \\
\hline $7 / 23$ & 56 & 52 & 63 & 50 & $8 / 27$ & 49 & 48 & -- & - \\
\hline $7 / 24$ & 56 & 53 & 58 & 50 & -- & -- & - & -- & -- \\
\hline
\end{tabular}


Table 4 - DDT content and turbidity of water from Canyon Creek and Trapper Creek, 1956

\begin{tabular}{|c|c|c|c|c|c|}
\hline \multirow[b]{2}{*}{ ID no. I/ } & \multicolumn{2}{|c|}{ Sample time } & \multirow[b]{2}{*}{ Location } & \multirow[b]{2}{*}{$\begin{array}{c}\text { DDT } \\
\text { (p.p.m.) }\end{array}$} & \multirow[b]{2}{*}{$\begin{array}{l}\text { Turbidity } \\
\text { (p.p.m.) }\end{array}$} \\
\hline & Date & Hour & & & \\
\hline 30464 & $7 / 2$ & $\begin{array}{l}\text { Time of } \\
\text { spraying }\end{array}$ & $\begin{array}{l}\text { Canyon Cryeek } \\
\text { bridge } \underline{3}\end{array}$ & 0.10 & 0.09 \\
\hline 30465 & $7 / 2$ & $\begin{array}{l}\frac{1}{2} \mathrm{hrs.} \text { after } \\
\text { spraying }\end{array}$ & $\begin{array}{l}\text { Canyon Creek } \\
\text { bridge } 2 /\end{array}$ & 0.33 & - \\
\hline 30467 & $7 / 3$ & $\begin{array}{l}27 \text { hrs. after } \\
\text { spraying }\end{array}$ & $\begin{array}{l}\text { Canyon Creek } \\
\text { bridge 2/ }\end{array}$ & 0 & - \\
\hline 30468 & $7 / 3$ & $\begin{array}{l}36 \text { hrs. aftyer } \\
\text { spraying } \underline{3}\end{array}$ & $\begin{array}{l}\text { Canyon Creek } \\
\text { bridge } 2 /\end{array}$ & 0 & - \\
\hline & $7 / 2$ & & $\begin{array}{l}\text { Trapper Creek } \\
\text { at smelter }\end{array}$ & - & 1.0 \\
\hline
\end{tabular}

1/ Chemical analyses made by the Entomology Research Division, Agricultural Research Service, U. S. Department of Agriculture, Beltsville, Md.

2/ The samples on Canyon Creek were taken at aquatic insect bottom station 6 or live car station $V$ where the average amount of DDT reaching the water was 0.32 pound per acre.

3) Taken $1 \mathrm{hr}$. after 1.2 inches of rain. 
Table 5 - Numbers of trout collected by shocking, Canyon Creek, 1956-1957

\begin{tabular}{|c|c|c|c|c|c|c|c|c|c|c|c|c|c|c|}
\hline & Spray I] & & & July 1 & $3-16,1$ & 956 & & August & $13-14,1$ & 1956 & & August & $6-7,195$ & \\
\hline $\begin{array}{c}\text { Station } \\
\text { No. }\end{array}$ & $\begin{array}{l}\text { (Ibs. } \\
\text { DDT per } \\
\text { acre) }\end{array}$ & $\begin{array}{l}\text { Species } \\
\text { of } \\
\text { fish 2 }\end{array}$ & $\begin{array}{l}\text { No. } \\
\text { fish }\end{array}$ & $\begin{array}{c}\text { - Aver } \\
\text { Length } \\
\text { (inches) }\end{array}$ & $\begin{array}{l}\text { age - } \\
\text { Weight } \\
\text { (lbs.) }\end{array}$ & $\begin{array}{l}\text { Condition } \\
\text { factor }\end{array}$ & $\begin{array}{l}\text { No. } \\
\text { fish }\end{array}$ & $\begin{array}{l}\text { - Aver } \\
\text { Length } \\
\text { (inches) }\end{array}$ & $\begin{array}{l}\text { age - } \\
\text { Weight } \\
\text { (lbs.) }\end{array}$ & $\begin{array}{l}\text { Condition } \\
\text { factor }\end{array}$ & $\begin{array}{l}\text { No. } \\
\text { fish }\end{array}$ & $\begin{array}{l}\text { - Avere } \\
\text { Length } \\
\text { (inches) }\end{array}$ & $\begin{array}{l}\text { age - } \\
\text { Weight } \\
\text { (Ibs.) }\end{array}$ & $\begin{array}{l}\text { Condition } \\
\text { factor }\end{array}$ \\
\hline $\begin{array}{c}\text { Un- } \\
\text { sprayed } \\
1 \\
\end{array}$ & 0 & $\mathrm{Rb} \stackrel{\mathrm{Eb}}{\&} \mathrm{Ct}$ & $\begin{array}{l}2 \\
1 \\
\end{array}$ & $\begin{array}{l}6.4 \\
6.3 \\
\end{array}$ & $\begin{array}{l}0.17 \\
0.12\end{array}$ & $\begin{array}{l}41.3 \\
48.1 \\
\end{array}$ & $\begin{array}{r}11 \\
3\end{array}$ & $\begin{array}{l}6.0 \\
7.0\end{array}$ & $\begin{array}{l}0.09 \\
0.13 \\
\end{array}$ & $\begin{array}{l}33.1 \\
37.5\end{array}$ & $\begin{array}{r}16 \\
7 \\
\end{array}$ & $\begin{array}{l}6.0 \\
5.8 \\
\end{array}$ & $\begin{array}{l}0.12 \\
0.08 \\
\end{array}$ & $\begin{array}{l}44.3 \\
37 \cdot 2 \\
\end{array}$ \\
\hline$\underset{4}{\text { Sprayed }}$ & 0.01 & $\mathrm{Rb} \& \mathrm{Cb}$ & $\begin{array}{r}17 \\
7\end{array}$ & $\begin{array}{l}6.2 \\
6.4\end{array}$ & $\begin{array}{l}0.12 \\
0.12\end{array}$ & $\begin{array}{l}42.3 \\
34.7\end{array}$ & $\begin{array}{r}18 \\
7\end{array}$ & $\begin{array}{l}6.4 \\
6.2\end{array}$ & $\begin{array}{l}0.11 \\
0.09\end{array}$ & $\begin{array}{l}35.9 \\
33.2\end{array}$ & $\begin{array}{r}16 \\
9\end{array}$ & $\begin{array}{l}6.1 \\
7.6\end{array}$ & $\begin{array}{l}0.12 \\
0.19\end{array}$ & $\begin{array}{l}43.2 \\
40.0\end{array}$ \\
\hline 5 & 0.32 & $\begin{array}{c}\mathrm{Eb} \\
\mathrm{Rb} \& \mathrm{Ct}\end{array}$ & $\frac{11}{16}$ & $\begin{array}{l}6.9 \\
5.3\end{array}$ & $\begin{array}{l}0.15 \\
0.08\end{array}$ & $\begin{array}{l}40.5 \\
38.2\end{array}$ & $\begin{array}{r}8 \\
12\end{array}$ & $\begin{array}{l}6.6 \\
5.5\end{array}$ & $\begin{array}{l}0.12 \\
0.06\end{array}$ & $\begin{array}{l}38.5 \\
29.4\end{array}$ & $\begin{array}{l}6 \\
6\end{array}$ & $\begin{array}{l}6.8 \\
4.5\end{array}$ & $\begin{array}{l}0.13 \\
0.04\end{array}$ & $\begin{array}{l}39.3 \\
36.7\end{array}$ \\
\hline 6 & 0.32 & $\mathrm{Rb} \& \mathrm{Ct}$ & $\begin{array}{r}20 \\
2\end{array}$ & $\begin{array}{l}5.3 \\
6.0\end{array}$ & $\begin{array}{l}0.07 \\
0.09\end{array}$ & $\begin{array}{l}36.2 \\
36.8\end{array}$ & $\begin{array}{r}22 \\
3\end{array}$ & $\begin{array}{l}5.0 \\
6.2\end{array}$ & $\begin{array}{l}0.05 \\
0.09\end{array}$ & $\begin{array}{l}36.6 \\
33.4\end{array}$ & $\begin{array}{r}26 \\
3\end{array}$ & $\begin{array}{l}5.6 \\
6.0\end{array}$ & $\begin{array}{l}0.07 \\
0.10\end{array}$ & $\begin{array}{l}41.4 \\
42.6\end{array}$ \\
\hline 7 & 0.32 & $\mathrm{Rb} \& \mathrm{Cb}$ & $\begin{array}{r}68 \\
1\end{array}$ & $\begin{array}{l}6.5 \\
4.7\end{array}$ & $\begin{array}{l}0.11 \\
0.04\end{array}$ & $\begin{array}{l}32.8 \\
38.6\end{array}$ & $\begin{array}{r}65 \\
5\end{array}$ & $\begin{array}{l}6.3 \\
6.7\end{array}$ & $\begin{array}{l}0.10 \\
0.14\end{array}$ & $\begin{array}{l}31.3 \\
29.7\end{array}$ & $\begin{array}{r}37 \\
2\end{array}$ & $\begin{array}{l}5.7 \\
6.2\end{array}$ & $\begin{array}{l}0.09 \\
0.09\end{array}$ & $\begin{array}{l}40.6 \\
38.1\end{array}$ \\
\hline $\begin{array}{l}\text { Grand T } \\
\text { or Aver } \\
\text { Sprayed }\end{array}$ & $\begin{array}{l}\text { otal } \\
\text { age } \\
\text { Stations }\end{array}$ & $\begin{array}{c}\mathrm{Eb} \\
\mathrm{Rb} \text { \& } \mathrm{Ct}\end{array}$ & $\frac{176}{26}$ & $\begin{array}{l}6.3 \\
5.7\end{array}$ & $\begin{array}{l}0.11 \\
0.09\end{array}$ & $\begin{array}{l}36.2 \\
37.1\end{array}$ & $\begin{array}{r}113 \\
27\end{array}$ & $\begin{array}{l}6.1 \\
6.0\end{array}$ & $\begin{array}{l}0.10 \\
0.09\end{array}$ & $\begin{array}{l}33.6 \\
31.1\end{array}$ & $\begin{array}{l}85 \\
20\end{array}$ & $\begin{array}{l}5.8 \\
6.3\end{array}$ & $\begin{array}{l}0.09 \\
0.12\end{array}$ & $\begin{array}{l}41.3 \\
39.7\end{array}$ \\
\hline
\end{tabular}

I/ Spray reaching ground.

2/ Eb - eastern brook trout; $\mathrm{Rb}$ \& Ct - rainbow trout, cutthroat trout and rainbow $\mathrm{x}$ cutthroat hybrid. 
Table 6 - Numbers of trout collected by shocking, Trapper Creek, 1956-1957

\begin{tabular}{|c|c|c|c|c|c|c|c|c|c|c|c|c|c|c|}
\hline \multirow[b]{2}{*}{$\begin{array}{c}\text { Station } \\
\text { No. }\end{array}$} & \multirow{2}{*}{$\begin{array}{l}\text { Spray } 1] \\
\text { (Ibs. } \\
\text { DDT per } \\
\text { a.cre) }\end{array}$} & \multirow[b]{2}{*}{$\begin{array}{l}\text { Species } \\
\text { of } \\
\text { fish ?/ }\end{array}$} & \multicolumn{4}{|c|}{ July $16-17,1956$} & \multicolumn{4}{|c|}{$\frac{\text { August } 15-16,1956}{\text { - Average - }}$} & \multicolumn{4}{|c|}{ August $7-9,1957$} \\
\hline & & & $\begin{array}{l}\text { No. } \\
\text { fish }\end{array}$ & $\begin{array}{l}\text { - Avera } \\
\text { Length } \\
\text { (inches) }\end{array}$ & $\begin{array}{l}\text { Weight } \\
\text { (Ibs.) }\end{array}$ & $\begin{array}{l}\text { Condition } \\
\text { factor }\end{array}$ & $\begin{array}{l}\text { No. } \\
\text { fish }\end{array}$ & $\begin{array}{l}\text { - Avera } \\
\text { Iength } \\
\text { (inches) }\end{array}$ & $\begin{array}{l}\text { Weight } \\
\text { (1bs.) }\end{array}$ & $\begin{array}{l}\text { Condition } \\
\text { factor }\end{array}$ & $\begin{array}{l}\text { No. } \\
\text { fish }\end{array}$ & $\begin{array}{c}\text { - Aver } \\
\text { Length } \\
\text { (inches) }\end{array}$ & $\begin{array}{l}\text { Weight } \\
\text { (Ibs.) }\end{array}$ & $\begin{array}{c}\text { Condition } \\
\text { factor }\end{array}$ \\
\hline 2 & 0.19 & Ro \& \& Ct & $\begin{array}{r}5 \\
11\end{array}$ & $\begin{array}{l}6.5 \\
6.7\end{array}$ & $\begin{array}{l}0.12 \\
0.11\end{array}$ & $\begin{array}{l}37.6 \\
34.6\end{array}$ & $\begin{array}{l}9 \\
6\end{array}$ & $\begin{array}{l}6.4 \\
5.8\end{array}$ & $\begin{array}{l}0.12 \\
0.09\end{array}$ & $\begin{array}{l}41.7 \\
36.8\end{array}$ & $\frac{11}{3}$ & $\begin{array}{l}6.4 \\
6.4\end{array}$ & $\begin{array}{l}0.13 \\
0.14\end{array}$ & $\begin{array}{l}45.8 \\
39.6\end{array}$ \\
\hline 4 & 0.19 & $\mathrm{Rb} \& \mathrm{~Eb}$ & $\begin{array}{r}45 \\
3\end{array}$ & $\begin{array}{l}5.3 \\
7.2\end{array}$ & $\begin{array}{l}0.06 \\
0.12\end{array}$ & $\begin{array}{l}34.8 \\
31.5\end{array}$ & $\begin{array}{r}82 \\
9\end{array}$ & $\begin{array}{l}5.3 \\
5.4\end{array}$ & $\begin{array}{l}0.06 \\
0.06\end{array}$ & $\begin{array}{l}35.7 \\
33.4\end{array}$ & $\begin{array}{l}82 \\
11\end{array}$ & $\begin{array}{l}5.2 \\
5.4\end{array}$ & $\begin{array}{l}0.06 \\
0.07\end{array}$ & $\begin{array}{l}43.0 \\
37.0\end{array}$ \\
\hline 5 & 0.19 & $\mathrm{Rb} \& \mathrm{Ct}$ & $\begin{array}{r}60 \\
4\end{array}$ & $\begin{array}{l}4.8 \\
7.0\end{array}$ & $\begin{array}{l}0.04 \\
0.12\end{array}$ & $\begin{array}{l}32.8 \\
33.9\end{array}$ & $\begin{array}{l}86 \\
13\end{array}$ & $\begin{array}{l}4.8 \\
6.2\end{array}$ & $\begin{array}{l}0.05 \\
0.10\end{array}$ & $\begin{array}{l}35.7 \\
40.6\end{array}$ & $\begin{array}{r}52 \\
7\end{array}$ & $\begin{array}{l}4.8 \\
5.9\end{array}$ & $\begin{array}{l}0.05 \\
0.11\end{array}$ & $\begin{array}{l}43.0 \\
39.2\end{array}$ \\
\hline 6 & 0.10 & $\mathrm{Rb} \& \mathrm{Ct}$ & $\begin{array}{r}47 \\
1\end{array}$ & $\begin{array}{r}5.6 \\
10.0\end{array}$ & $\begin{array}{l}0.08 \\
0.32\end{array}$ & $\begin{array}{l}35.4 \\
32.0\end{array}$ & $\begin{array}{r}78 \\
4\end{array}$ & $\begin{array}{l}5.7 \\
7.3\end{array}$ & $\begin{array}{l}0.07 \\
0.14\end{array}$ & $\begin{array}{l}32.5 \\
32.3\end{array}$ & $\begin{array}{r}73 \\
4\end{array}$ & $\begin{array}{l}5.6 \\
5.1\end{array}$ & $\begin{array}{l}0.08 \\
0.06\end{array}$ & $\begin{array}{l}40.7 \\
40.0\end{array}$ \\
\hline 7 & $\begin{array}{l}\text { Below } \\
\text { Spray } \\
\text { I mile }\end{array}$ & $\mathrm{Rb} \& \mathrm{Ct}$ & $\begin{array}{r}52 \\
1\end{array}$ & $\begin{array}{l}5.5 \\
4.4\end{array}$ & $\begin{array}{l}0.08 \\
0.02\end{array}$ & $\begin{array}{l}34 \cdot 9 \\
23 \cdot 3\end{array}$ & $\begin{array}{l}37 \\
--\end{array}$ & $\begin{array}{l}5.9 \\
-\end{array}$ & 0.09 & 34.8 & $\begin{array}{r}44 \\
2\end{array}$ & $\begin{array}{l}5.5 \\
8.0\end{array}$ & $\begin{array}{l}0.09 \\
0.24\end{array}$ & $\begin{array}{l}45.2 \\
40.4\end{array}$ \\
\hline $\begin{array}{l}\text { Grand To } \\
\text { or Avera } \\
\text { Sprayed }\end{array}$ & $\begin{array}{l}\text { otal } \\
\text { age } \\
\text { Stations }\end{array}$ & $\begin{array}{l}\mathrm{Eb} \\
\mathrm{Kb}\end{array}$ & $\begin{array}{r}209 \\
20\end{array}$ & $\begin{array}{l}5.3 \\
6.9\end{array}$ & $\begin{array}{l}0.06 \\
0.12\end{array}$ & $\begin{array}{l}34.4 \\
33 \cdot 3\end{array}$ & $\begin{array}{r}292 \\
32\end{array}$ & $\begin{array}{l}5.4 \\
6.0\end{array}$ & $\begin{array}{l}0.06 \\
0.09\end{array}$ & $\begin{array}{l}33.6 \\
36.8\end{array}$ & $\begin{array}{r}262 \\
27\end{array}$ & $\begin{array}{l}5.3 \\
5.8\end{array}$ & $\begin{array}{l}0.07 \\
0.10\end{array}$ & $\begin{array}{l}42.9 \\
38.7\end{array}$ \\
\hline
\end{tabular}

\section{I) Spray reaching ground.}

2/ Eb - eastern brook trout; Rb \& Ct - rainbow trout, cutthroat trout and rainbow $x$ cutthroat hybrid. 


\begin{tabular}{|c|c|c|c|c|c|c|c|c|c|}
\hline \multirow[b]{2}{*}{$\begin{array}{l}\text { Live car } \\
\text { number }\end{array}$} & \multirow[b]{2}{*}{$\begin{array}{c}\text { Date \& hour } \\
\text { fish placed } \\
\text { in cars }\end{array}$} & \multicolumn{4}{|c|}{ Species } & \multicolumn{4}{|c|}{ Number of dead trout } \\
\hline & & $\begin{array}{l}\text { E. } \\
\text { No. }\end{array}$ & $\begin{array}{l}\text { Brook } \\
\text { size } \\
\text { (inches) }\end{array}$ & $\begin{array}{l}\text { RaI } \\
\text { No. }\end{array}$ & $\begin{array}{l}\text { Inbow } \\
\text { size } \\
\text { (inches) }\end{array}$ & $\begin{array}{l}\text { Number } \\
\text { of trout } \\
\text { in car }\end{array}$ & $\begin{array}{l}\text { Prespray } \\
6 / 30-7 / 1\end{array}$ & $\begin{array}{c}\text { Spray } \\
\text { day } \\
7 / 2\end{array}$ & $\begin{array}{l}\text { Post- } \\
\text { spray } 1 \\
7 / 3-7 / 5\end{array}$ \\
\hline $\begin{array}{l}\text { I } \\
\text { Fool at } \\
\text { dude ranch }\end{array}$ & $\begin{array}{l}6 / 29 \\
9: 00 \text { a.m. }\end{array}$ & $\begin{array}{l}1 \\
2 \\
1 \\
3\end{array}$ & $\begin{array}{l}8 \\
9 \\
7 \\
5\end{array}$ & $\begin{array}{l}1 \\
1 \\
1\end{array}$ & $\begin{array}{r}10 \\
8 \\
5\end{array}$ & 10 & 0 & 0 & 0 \\
\hline $\begin{array}{l}I I \\
\text { Scocking } \\
\text { atation }\end{array}$ & $\begin{array}{l}6 / 29 \\
8: 30 \text { a.m. }\end{array}$ & $\begin{array}{l}1 \\
2 \\
1 \\
2 \\
1 \\
2\end{array}$ & $\begin{array}{r}11 \\
10 \\
8 \\
7 \\
6 \\
5\end{array}$ & 1 & 9 & 10 & 0 & 0 & 0 \\
\hline $\begin{array}{l}\text { IIII } \\
\text { Canyon } \\
\text { Creek } \\
\text { cabin }\end{array}$ & $\begin{array}{l}6 / 29 \\
8: 00 \text { a.m. }\end{array}$ & $\begin{array}{l}2 \\
1\end{array}$ & $\begin{array}{l}6 \\
5\end{array}$ & $\begin{array}{l}1 \\
2 \\
2 \\
3\end{array}$ & $\begin{array}{r}11 \\
10 \\
8 \\
7\end{array}$ & 11 & 0 & 0 & 0 \\
\hline $\begin{array}{l}\text { IV } \\
\text { Camp area } \\
\text { shocking } \\
\text { station }\end{array}$ & $\begin{array}{l}6 / 29 \\
9: 30 \text { a.m. }\end{array}$ & $\begin{array}{l}1 \\
1 \\
1 \\
1 \\
5\end{array}$ & $\begin{array}{l}9 \\
8 \\
7 \\
4 \\
3\end{array}$ & 1 & 7 & 10 & 0 & 0 & 0 \\
\hline $\begin{array}{l}\mathrm{V} \\
\text { Pool at } \\
\text { bridge }\end{array}$ & $\begin{array}{c}6 / 29 \\
10: 00 \text { a.m. }\end{array}$ & $\begin{array}{l}1 \\
1 \\
4 \\
3\end{array}$ & $\begin{array}{l}8 \\
7 \\
6 \\
5\end{array}$ & 1 & 9 & 10 & 0 & 0 & 0 \\
\hline $\begin{array}{l}\text { VI } \\
200 \text { yds. } \\
\text { selow } \\
\text { bridge }\end{array}$ & $\begin{array}{c}6 / 29 \\
10: 15 \text { a.m. }\end{array}$ & $\begin{array}{l}1 \\
2 \\
4 \\
2\end{array}$ & $\begin{array}{l}7 \\
6 \\
5 \\
4\end{array}$ & 1 & 6 & 10 & 0 & 0 & 0 \\
\hline $\begin{array}{l}\text { VII } \\
350 \text { yds. } \\
\text { below } \\
\text { bridge }\end{array}$ & $\begin{array}{c}6 / 29 \\
10: 30 \text { a.m. }\end{array}$ & $\begin{array}{l}2 \\
1 \\
3 \\
2 \\
1\end{array}$ & $\begin{array}{l}8 \\
7 \\
6 \\
5 \\
3\end{array}$ & 1 & 6 & 10 & 0 & 0 & 0 \\
\hline $\begin{array}{l}\text { VIII } \\
\text { Old corral } \\
\text { and ranch } \\
\text { Louse }\end{array}$ & 11:00 a.m. & $\begin{array}{l}1 \\
1 \\
1 \\
1 \\
1 \\
3 \\
63\end{array}$ & $\begin{array}{r}10 \\
9 \\
6 \\
5 \\
4 \\
3 \\
\end{array}$ & 1 & 9 & 9 & 0 & 0 & 0 \\
\hline & TOTAIS & 63 & & 17 & & 80 & 0 & 0 & 0 \\
\hline
\end{tabular}

II All fish removed from live cars on July 6 were in good condition. 
Table 8 - Survival of trout in live cars, Trapper Creek, 1956

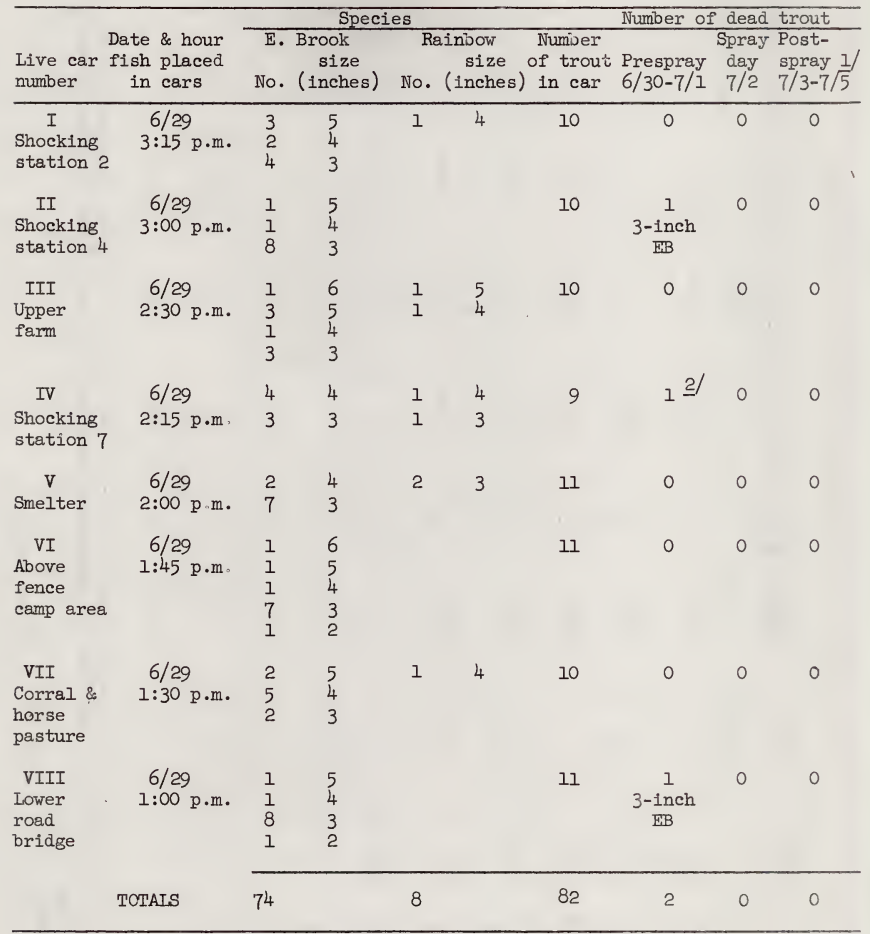

I/ All fish removed from live cars on July 6 were in good condition.

2/ Killed by rock. 
Table 9 - Ansiysis of tissues from trout exposed to DDT, 1926 I/

\begin{tabular}{|c|c|c|c|c|c|c|c|c|}
\hline \multirow{2}{*}{$\begin{array}{l}\text { Stream } \\
\text { \& } \\
\text { Iocation }\end{array}$} & \multirow{2}{*}{$\begin{array}{c}\text { Date } \\
\text { collected }\end{array}$} & \multirow{2}{*}{$\begin{array}{c}\text { Number } \\
\& \\
\text { Species }\end{array}$} & \multicolumn{6}{|c|}{ Concentration of DDT - micrograms per milligram of dry tissue } \\
\hline & & & Brain & Liver & Kidney & $\begin{array}{l}\text { Pyloric } \\
\text { caeca }\end{array}$ & $\begin{array}{l}\text { Visceral } \\
\text { fat }\end{array}$ & $\begin{array}{l}\text { Whole fish } \\
\text { homogenates }\end{array}$ \\
\hline $\begin{array}{l}\text { Trapper } \mathrm{Cr} \text {. } \\
\text { Station } 5\end{array}$ & $7 / 4$ & $\begin{array}{r}3 \\
\mathrm{~Eb}\end{array}$ & Trace & 2] & 2] & Trace & 1.15 & \\
\hline $\begin{array}{l}\text { Trapper } \mathrm{Cr} \text {. } \\
\text { Station } 5\end{array}$ & $7 / 4$ & $\begin{aligned} 3 \\
\mathrm{~Eb}\end{aligned}$ & 2) & 2/ & 2) & 2] & 2) & \\
\hline $\begin{array}{l}\text { Trapper } \mathrm{Cr} \text {. } \\
\text { Station } 5\end{array}$ & $7 / 4$ & $\begin{array}{r}1 \\
\mathrm{~Eb}\end{array}$ & Trace & 2) & 2) & 0.03 & 0.18 & \\
\hline $\begin{array}{l}\text { Canyon } \mathrm{Cr} \text {. } \\
\text { Live Car V }\end{array}$ & $7 / 6$ & $\stackrel{2}{\mathrm{~Eb}}$ & 2/ & 2/ & 0.34 & 2) & 0.79 & \\
\hline $\begin{array}{l}\text { Canyon } \mathrm{Cr} \text {. } \\
\text { Live Car V }\end{array}$ & $7 / 6$ & $\begin{array}{r}2 \\
\mathrm{~Eb}\end{array}$ & 2) & 2) & Trace & 0.04 & Trace & \\
\hline $\begin{array}{l}\text { Canyon } \mathrm{Cr} \text {. } \\
\text { above cabin }\end{array}$ & $8 / 16$ & $\begin{array}{r}1 \\
\mathrm{~Eb} \\
1 \\
\mathrm{Ct}\end{array}$ & -- & - & - & -- & -- & 0.01 \\
\hline $\begin{array}{l}\text { Trapper } \mathrm{Cr} \text {. } \\
\text { Station } 4\end{array}$ & $8 / 17$ & $\begin{array}{r}2 \\
C t\end{array}$ & -- & -- & -- & - & -- & 2) \\
\hline $\begin{array}{l}\text { Trapper } \mathrm{Cr} \text {. } \\
\text { Station } 4\end{array}$ & $8 / 17$ & $\begin{array}{c}2 \\
\mathrm{~Eb}\end{array}$ & 2) & 2) & 2) & 2) & 2) & \\
\hline $\begin{array}{l}\text { Canyon } \mathrm{Cr} \\
\text { Station } 6\end{array}$ & $10 / 20$ & $\begin{array}{c}1 \\
C t\end{array}$ & Trace & 2) & 2/ & ㄱ) & 4.0 & \\
\hline
\end{tabular}


Table 10 - Summary of the volumes of food in trout stomachs from Canyon and Trapper Creeks and from live cars held in these streams, 1956

\begin{tabular}{|c|c|c|c|c|c|c|c|}
\hline \multirow[b]{2}{*}{ Location } & \multirow[b]{2}{*}{ Date } & \multirow{2}{*}{$\begin{array}{l}\text { Vol. } \\
\text { (fish } \\
\text { in } \mathrm{cc}_{0} \text { ) }\end{array}$} & \multirow{2}{*}{$\begin{array}{l}\text { Spray } \\
\text { (Ibs. } \\
\text { per } \\
\text { acre) }\end{array}$} & \multicolumn{3}{|c|}{ Trout } & \multirow[b]{2}{*}{$\begin{array}{l}\text { Predominant } \\
\text { forms }\end{array}$} \\
\hline & & & & No. & $\begin{array}{c}\text { Size } \\
\text { (inches) }\end{array}$ & $\begin{array}{l}\text { Species } 1 / \\
\text { of fish } 1\end{array}$ & \\
\hline Canyon Cr. & $6 / 28$ & $\frac{\text { STOMACHS }}{3.85}$ & $\frac{\text { FROM F }}{0}$ & $\frac{\text { ISH T }}{8}$ & $\frac{\text { AKEN FROM }}{6 \text { to } 11}$ & $\frac{\text { STREAMS }}{\text { CT, EBB, }}$ & $\begin{array}{l}\text { Caddisfly, stone- } \\
\text { fly nymphs (pre- } \\
\text { spray) }\end{array}$ \\
\hline $\begin{array}{l}\text { Station } 5 \\
\text { Trapper } \mathrm{Cr} .\end{array}$ & $7 / 4$ & 2.64 & 0.19 & 5 & 4 to 5 & $\mathrm{EBB}$ & $\begin{array}{l}\text { Caddisfly and } \\
\text { mayfly nymphs }\end{array}$ \\
\hline $\begin{array}{l}\text { Station } 4 \\
\text { Trapper } \mathrm{Cr} .\end{array}$ & $7 / 4$ & 5.00 & 0.19 & $\begin{array}{r}7 \\
11 \\
1\end{array}$ & $\begin{array}{l}6 \\
7 \\
5\end{array}$ & $\begin{array}{l}E B B \\
E B B \\
E B B\end{array}$ & $\begin{array}{l}\text { Stonefly and } \\
\text { mayfly nymphs }\end{array}$ \\
\hline $\begin{array}{l}\text { Station } 5 \\
\text { Trapper } \mathrm{Cr} \text {. }\end{array}$ & $7 / 11$ & 0.90 & 0.19 & 1 & 10 & $\mathrm{~EB}$ & $\begin{array}{l}\text { Ants and aerial } \\
\text { forms }\end{array}$ \\
\hline $\begin{array}{l}\text { Station } 8 \\
\text { Canyon } \mathrm{Cr} \text {. }\end{array}$ & $8 / 1$ & 0.55 & 0.32 & $\begin{array}{l}1 \\
3\end{array}$ & 6 to 8 & $\begin{array}{l}\mathrm{RB} \\
\mathrm{EB}\end{array}$ & $\begin{array}{l}\text { Ants and aerial } \\
\text { forms }\end{array}$ \\
\hline $\begin{array}{l}\text { Station } 5 \\
\text { Canyon } \mathrm{Cr} .\end{array}$ & $8 / 2$ & 7.00 & 0.32 & $\begin{array}{l}1 \\
1\end{array}$ & $\begin{array}{r}12 \\
8\end{array}$ & $\begin{array}{l}\mathrm{RB} \\
\mathrm{EB}\end{array}$ & Fly larvae \\
\hline $\begin{array}{l}\text { Station } 5 \\
\text { Canyon } \mathrm{Cr} \text {. }\end{array}$ & $8 / 2$ & 1.00 & 0.32 & 1 & 8 & $\mathrm{EBB}$ & Ants \\
\hline $\begin{array}{l}\text { Station } 6 \\
\text { Trapper } \mathrm{Cr} \text {. }\end{array}$ & $8 / 16$ & 0.15 & 0.10 & 2 & 7 & $\mathrm{~EB}$ & $\begin{array}{l}\text { Flies and aerial } \\
\text { forms }\end{array}$ \\
\hline $\begin{array}{l}\text { Station } 5 \\
\text { Canyon Cr. }\end{array}$ & $8 / 17$ & 2.00 & 0.32 & 2 & 7 & $\mathrm{~EB}$ & $\begin{array}{l}\text { Ants and aerial } \\
\text { forms }\end{array}$ \\
\hline $\begin{array}{l}\text { Station } 4 \\
\text { Trapper } \mathrm{Cr} \text {. }\end{array}$ & $8 / 17$ & 0.25 & 0.19 & 2 & 6 & СT & $\begin{array}{l}\text { Ants and fly } \\
\text { larvae }\end{array}$ \\
\hline $\begin{array}{l}\text { Station } 4 \\
\text { Trapper } \mathrm{Cr} \text {. }\end{array}$ & $8 / 17$ & 0.20 & 0.19 & 10 & 6 to 8 & EBB & Aerial forms \\
\hline $\begin{array}{l}\text { Station } 5 \\
\text { Canyon Cr. }\end{array}$ & $8 / 21$ & $\begin{array}{l}1.26 \\
\text { STOMAC }\end{array}$ & $\begin{array}{r}0.32 \\
\text { S FRON }\end{array}$ & $\begin{array}{c}4 \\
5 \\
\text { FISH } \\
\end{array}$ & $\begin{array}{c}8 \\
7 \text { to } 8 \frac{1}{2} \\
\text { HEID IN LII }\end{array}$ & $\begin{array}{l}\text { FBB } \\
\text { CT } \\
\text { VE CARS }\end{array}$ & Mayfly nymphs \\
\hline $\begin{array}{l}\text { Cage I } \\
\text { Trapper Cr. }\end{array}$ & $7 / 6$ & 0.40 & 0.19 & 1 & 5 & $\mathrm{EBB}$ & $\begin{array}{l}\text { Stonefly and } \\
\text { mayfly nymphs }\end{array}$ \\
\hline $\begin{array}{l}\text { Cage II } \\
\text { Trapper } \mathrm{Cr} \text {. }\end{array}$ & $7 / 6$ & 1.80 & 0.19 & 1 & 5 & $\mathrm{EBB}$ & Mayfly nymphs \\
\hline $\begin{array}{l}\text { Cage IV } \\
\text { Trapper Cr. }\end{array}$ & $7 / 6$ & 2.60 & 0 & 1 & 4 & $\mathrm{EBB}$ & Mayfly nymphs \\
\hline $\begin{array}{l}\text { Cage V } \\
\text { Trapper Cr. }\end{array}$ & $7 / 6$ & 0.30 & 0 & 1 & 4 & $\mathrm{~EB}$ & $\begin{array}{l}\text { Caddisfly } \\
\text { nymphs }\end{array}$ \\
\hline Cages VI-VII & $7 / 6$ & 1.70 & 0 & 2 & 4 & $E B$ & Caddisfly nymphs \\
\hline $\begin{array}{l}\text { Cage VIII } \\
\text { Trapper } \mathrm{Cr} \text {. }\end{array}$ & $7 / 6$ & 0.40 & 0 & 1 & 4 & $\mathrm{EBB}$ & $\begin{array}{l}\text { Caddisfly and } \\
\text { stonefly nymphs }\end{array}$ \\
\hline $\begin{array}{l}\text { Cage IV } \\
\text { Canyon } \mathrm{Cr} .\end{array}$ & $7 / 6$ & 3.90 & 0.32 & 1 & 7 & EBB & Mayfly nymphs \\
\hline $\begin{array}{l}\text { Cage I } \\
\text { Canyon } \mathrm{Cr} .\end{array}$ & $7 / 6$ & 0.90 & 0 & 1 & 7 & EBB & Caddisfly nymphs \\
\hline $\begin{array}{l}\text { Cage VIII } \\
\text { Canyon } \mathrm{Cr} \text {. }\end{array}$ & $7 / 6$ & 2.50 & 0 & 1 & 7 & EBB & Stonefly nymphs \\
\hline
\end{tabular}


Table 11 - Volumes of insects collected in 5-minute drift samples, Canyon Creek, 1956

\begin{tabular}{|c|c|c|c|c|c|}
\hline Date & Hour & & $\begin{array}{l}\text { Volume } \\
\text { (ce.) }\end{array}$ & Predominant forms & Remarks \\
\hline $\begin{array}{l}7 / 1 \\
7 / 2 \\
7 / 2 \\
7 / 2 \\
7 / 2 \\
7 / 2 \\
7 / 2\end{array}$ & $\begin{array}{r}6: 30 \\
7: 30 \\
10: 45 \\
2: 45 \\
6: 45 \\
10: 00\end{array}$ & $\begin{array}{l}\text { a.m. } \\
\text { a.m. } \\
\text { a.m. } \\
\text { p.m. } \\
\text { p.m. } \\
\text { a.m. }\end{array}$ & $\begin{array}{r}1.5 \\
150.0 \\
110.0 \\
65.0 \\
50.0 \\
55.0 \\
1.5\end{array}$ & $\begin{array}{l}\text { Mayflies } \\
\text { Stoneflies, mayflies, caddisflies } \\
\text { Stoneflies, mayflies, caddisflies } \\
\text { Stoneflies, mayflies, caddisflies } \\
\text { Stoneflies, mayflies, caddisflies } \\
\text { Stoneflies, mayflies, caddisflies } \\
\text { Miscellaneous }\end{array}$ & $\begin{array}{l}\text { Prespray } \\
\text { Spray day } \\
\text { Spray day } \\
\text { Spray day } \\
\text { Spray day } \\
\text { Spray day } \\
\text { Control } \\
\text { Station }\end{array}$ \\
\hline $\begin{array}{l}7 / 3 \\
7 / 4 \\
7 / 4 \\
7 / 5 \\
7 / 5 \\
7 / 6 \\
7 / 9\end{array}$ & $\begin{array}{l}8: 00 \\
7: 00 \\
5: 00 \\
7: 00 \\
5: 00 \\
7: 00 \\
8: 00\end{array}$ & $\begin{array}{l}\text { a.m. } \\
\text { a.m. } \\
\text { p.m. } \\
\text { a.m. } \\
\text { p.m. } \\
\text { a.m. } \\
\text { a.m. }\end{array}$ & $\begin{array}{l}1.5 \\
2.1 \\
1.3 \\
1.3 \\
0.3 \\
1.2 \\
0.1\end{array}$ & $\begin{array}{l}\text { Mayflies } \\
\text { Mayflies and caddisflies } \\
\text { Mayflies } \\
\text { Mayflies } \\
\text { Ants } \\
\text { Mayflies } \\
\text { Mayflies }\end{array}$ & Postspray \\
\hline $7 / 10$ & $-9 / 18$ & & $\begin{array}{l}\text { Neglig } \\
\text { of fly }\end{array}$ & $\begin{array}{l}\text { jible trace amounts, except small tem } \\
\text { populations, } 7-27 \text { to } 8-10 \text { (average, }\end{array}$ & $\begin{array}{l}0.2 \text { cc.). } \\
0 .\end{array}$ \\
\hline $\begin{array}{r}9 / 19 \\
10 / 19\end{array}$ & & & $\begin{array}{l}0.1 \\
0.2\end{array}$ & $\begin{array}{l}\text { Mayflies and stoneflies } \\
\text { Stoneflies }\end{array}$ & \\
\hline $10 / 20$ & & & 2.9 & Mayflies & $\begin{array}{l}\text { Control } \\
\text { station }\end{array}$ \\
\hline $10 / 23$ & & & 0.15 & Mayflies & $\begin{array}{l}\text { Control } \\
\text { station }\end{array}$ \\
\hline $10 / 23$ & & & 0.1 & Stoneflies & \\
\hline
\end{tabular}

AII samples taken at "Cabin station" except those marked "Control station."

Table 12 - Volumes of insects collected in 5-minute drift samples, Trapper Creek, 1956

$\begin{array}{cccc}\text { Date Hour } & \text { Volume } \\ \left(\mathrm{cc}_{0}\right) & \text { Predominant forms } & \text { Remarks }\end{array}$

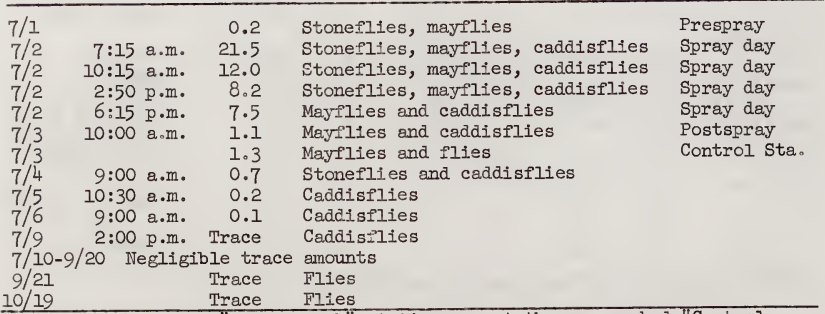

All samples taken at "Upper ranch" station except the one marked "Control station." 
Table 13 - Volume per square foot of predominant stream bottom invertebrates collected in Canyon Creek, 1956-1957

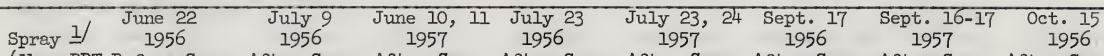

(1bs. DDT Before Spray After Spray After Spray After Spray After Spray After Spray After Spray After Spray

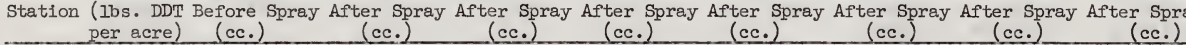

\begin{tabular}{|c|c|c|c|c|c|c|c|c|c|}
\hline 1 & $\begin{array}{c}0 \\
\text { Control }\end{array}$ & $\begin{array}{c}0.24 \\
\text { mayflies }\end{array}$ & $\begin{array}{c}0.30 \\
\text { mayflies }\end{array}$ & $\begin{array}{c}0.18 \\
\text { mayflies }\end{array}$ & $\begin{array}{c}0.41 \\
\text { mayflies }\end{array}$ & $\begin{array}{l}0.66 \\
\text { mayflies, } \\
\text { caddisflies }\end{array}$ & $\begin{array}{l}0.72 \\
\text { caddisflies, } \\
\text { stoneflies }\end{array}$ & $\begin{array}{l}0.64 \\
\text { mayflies, } \\
\text { stoneflies }\end{array}$ & $\begin{array}{c}0.70 \\
\text { mayflies } \\
\text { stoneflies }\end{array}$ \\
\hline 2 & $\begin{array}{c}0 \\
\text { Control }\end{array}$ & $\begin{array}{c}0.34 \\
\text { mayflies }\end{array}$ & $\begin{array}{c}0.45 \\
\text { mayflies }\end{array}$ & $\begin{array}{c}0.20 \\
\text { mayflies }\end{array}$ & $\begin{array}{c}0.42 \\
\text { mayflies }\end{array}$ & $\begin{array}{l}0.50 \\
\text { mayflies, } \\
\text { caddisflies }\end{array}$ & $\begin{array}{l}0.43 \\
\text { caddisflies, } \\
\text { stoneflies }\end{array}$ & $\begin{array}{l}0.50 \\
\text { mayflies, } \\
\text { stoneflies }\end{array}$ & $\begin{array}{l}0.72 \\
\text { mayflies, } \\
\text { stoneflies }\end{array}$ \\
\hline 3 & $\begin{array}{c}0 \\
\text { Control }\end{array}$ & $\begin{array}{c}0.10 \\
\text { mayflies }\end{array}$ & $\begin{array}{l}0.21 \\
\text { mayflies, } \\
\text { stoneflies }\end{array}$ & $\begin{array}{l}0.14 \\
\text { mayflies, } \\
\text { caddisflies }\end{array}$ & $\begin{array}{c}0.60 \\
\text { mayflies }\end{array}$ & $\begin{array}{l}0.78 \\
\text { mayflies, } \\
\text { caddisflies }\end{array}$ & $\begin{array}{c}1.26 \\
\text { mayflies }\end{array}$ & $\begin{array}{l}1.50 \\
\text { caddisflies, } \\
\text { mayflies }\end{array}$ & $\begin{array}{l}2.22 \\
\text { caddisflies, } \\
\text { stoneflies }\end{array}$ \\
\hline 4 & $\begin{array}{c}0.01 \\
\text { Average }\end{array}$ & $\begin{array}{c}0.34 \\
\text { mayflies }\end{array}$ & $\begin{array}{c}0.36 \\
\text { mayflies }\end{array}$ & $\begin{array}{c}0.10 \\
\text { mayflies }\end{array}$ & $\begin{array}{c}0.63 \\
\text { mayflies }\end{array}$ & $\begin{array}{l}0.34 \\
\text { mayflies, } \\
\text { caddisflies }\end{array}$ & $\begin{array}{c}0.35 \\
\text { caddisflies }\end{array}$ & $\begin{array}{l}0.98 \\
\text { caddisflies, } \\
\text { mayflies }\end{array}$ & $\begin{array}{c}0.82 \\
\text { stoneflies }\end{array}$ \\
\hline 5 & $\begin{array}{c}0.32 \\
\text { Average }\end{array}$ & $\begin{array}{l}\quad 0.64 \\
\text { stoneflies, } \\
\text { mayflies }\end{array}$ & 0.0 & $\begin{array}{c}0.08 \\
\text { mayflies, } \\
\text { stoneflies }\end{array}$ & $\begin{array}{c}0.08 \\
\text { mayflies }\end{array}$ & $\begin{array}{l}0.72 \\
\text { mayflies }\end{array}$ & $\begin{array}{c}0.03 \\
\text { stoneflies }\end{array}$ & $\begin{array}{l}0.50 \\
\text { mayflies, } \\
\text { caddisflies }\end{array}$ & $\begin{array}{c}0.32 \\
\text { stoneflies }\end{array}$ \\
\hline 6 & $\begin{array}{c}0.32 \\
\text { Average }\end{array}$ & $\begin{array}{l}0.70 \\
\text { stoneflies, } \\
\text { mayflies }\end{array}$ & $\begin{array}{c}0.01 \\
\text { mayflies }\end{array}$ & $\begin{array}{c}0.04 \\
\text { mayflies }\end{array}$ & $\begin{array}{c}0.03 \\
\text { mayflies }\end{array}$ & $\begin{array}{c}0.22 \\
\text { mayflies }\end{array}$ & $\begin{array}{c}0.01 \\
\text { stoneflies }\end{array}$ & $\begin{array}{l}0.58 \\
\text { mayflies, } \\
\text { stoneflies }\end{array}$ & $\begin{array}{c}0.20 \\
\text { stoneflies }\end{array}$ \\
\hline 7 & $\begin{array}{c}0.32 \\
\text { Average }\end{array}$ & $\begin{array}{c}0.79 \\
\text { mayflies, } \\
\text { stoneflies }\end{array}$ & $\begin{array}{c}0.04 \\
\text { mayflies }\end{array}$ & $\begin{array}{c}0.08 \\
\text { mayflies }\end{array}$ & $\begin{array}{c}0.02 \\
\text { beetles }\end{array}$ & $\begin{array}{c}0.31 \\
\text { mayflies }\end{array}$ & $\begin{array}{c}0.02 \\
\text { stoneflies }\end{array}$ & $\begin{array}{l}0.36 \\
\text { mayflies }\end{array}$ & $\begin{array}{c}0.20 \\
\text { stoneflies }\end{array}$ \\
\hline 8 & $\begin{array}{c}0.32 \\
\text { Average }\end{array}$ & $\begin{array}{l}1.78 \\
\text { mayflies, } \\
\text { caddisflies }\end{array}$ & $\begin{array}{c}0.05 \\
\text { mayflies }\end{array}$ & $\begin{array}{c}0.50 \\
\text { mayflies }\end{array}$ & $\begin{array}{l}0.01 \\
\text { flies }\end{array}$ & $\begin{array}{c}0.74 \\
\text { mayflies }\end{array}$ & $\begin{array}{l}0.09 \\
\text { flies }\end{array}$ & $\begin{array}{l}0.88 \\
\text { mayflies, } \\
\text { caddisflies }\end{array}$ & $\begin{array}{c}0.18 \\
\text { stoneflies }\end{array}$ \\
\hline 9 & $\begin{array}{l}0 \\
1 / 8^{\text {mile }} \\
\text { below }\end{array}$ & no sample & no sample & $\begin{array}{c}0.18 \\
\text { mayflies }\end{array}$ & no sample & $\begin{array}{c}0.66 \\
\text { mayflies }\end{array}$ & $\begin{array}{c}0.04 \\
\text { stoneflies }\end{array}$ & $\begin{array}{l}0.65 \\
\text { mayflies, } \\
\text { stoneflies }\end{array}$ & $\begin{array}{c}0.29 \\
\text { stoneflies }\end{array}$ \\
\hline
\end{tabular}


Table 14 - Volume per square foot of predominant stream bottom invertebrates collected in Trapper Creek, 1956-1957

\begin{tabular}{|c|c|c|c|c|c|c|c|c|c|}
\hline Station & $\begin{array}{l}\text { Spray } 1 / \\
\text { (1bs. DDT } \\
\text { per acre) }\end{array}$ & $\begin{array}{l}\text { June } 20,21 \\
1956 \\
\text { Before Spray } \\
\text { (cc.) }\end{array}$ & $\begin{array}{c}\text { July } 11-13 \\
1956 \\
\text { After Spray } \\
\text { (cc.) }\end{array}$ & $\begin{array}{c}\text { June 10,11 } \\
1957 \\
\text { After Spray } \\
\text { (cc.) }\end{array}$ & $\begin{array}{c}\text { July } 24,25 \\
1956 \\
\text { After Spray } \\
\text { (cc.) }\end{array}$ & $\begin{array}{c}\text { July } 23 \\
1957 \\
\text { After Spray } \\
\text { (cc.) }\end{array}$ & $\begin{array}{c}\text { Sept. } 19 \\
1956 \\
\text { After Spray } \\
\text { (cc.) }\end{array}$ & $\begin{array}{l}\text { Sept. } 18,24 \\
1957 \\
\text { After Spray } \\
\text { (cc.) }\end{array}$ & $\begin{array}{c}\text { Oct. } 19,22 \\
1956 \\
\text { After Spray } \\
\text { (cc.) }\end{array}$ \\
\hline 1 & $\begin{array}{c}0 \\
\text { Control }\end{array}$ & No sample & $\begin{array}{c}0.08 \\
\text { mayflies, } \\
\text { stoneflies }\end{array}$ & $\begin{array}{c}0.09 \\
\text { mayflies, } \\
\text { stoneflies }\end{array}$ & $\begin{array}{c}0.10 \\
\text { mayflies }\end{array}$ & $\begin{array}{l}0.66 \\
\text { mayflies, } \\
\text { caddisflies }\end{array}$ & $\begin{array}{c}0.31 \\
\text { stoneflies }\end{array}$ & $\begin{array}{c}0.69 \\
\text { caddisflies }\end{array}$ & $\begin{array}{c}0.46 \\
\text { mayflies, } \\
\text { stoneflies }\end{array}$ \\
\hline 2 & $\begin{array}{c}0.19 \\
\text { Average }\end{array}$ & $\begin{array}{c}0.26 \\
\text { mayflies }\end{array}$ & $\begin{array}{c}0.06 \\
\text { mayflies }\end{array}$ & $\begin{array}{c}0.02 \\
\text { mayflies }\end{array}$ & $\begin{array}{c}0.04 \\
\text { mayflies }\end{array}$ & $\begin{array}{l}0.50 \\
\text { mayflies, } \\
\text { caddisflies }\end{array}$ & $\begin{array}{c}0.13 \\
\text { stoneflies }\end{array}$ & $\begin{array}{l}\quad 0.82 \\
\text { caddisflies, } \\
\text { mayflies }\end{array}$ & $\begin{array}{c}0.22 \\
\text { mayflies, } \\
\text { stoneflies }\end{array}$ \\
\hline 3 & $\begin{array}{c}0.19 \\
\text { Average }\end{array}$ & $\begin{array}{c}0.46 \\
\text { mayflies }\end{array}$ & $\begin{array}{c}0.05 \\
\text { mayflies }\end{array}$ & $\begin{array}{l}0.12 \\
\text { mayflies, } \\
\text { caddisflies }\end{array}$ & $\begin{array}{c}0.23 \\
\text { mayflies }\end{array}$ & $\begin{array}{l}0.78 \\
\text { mayflies, } \\
\text { caddisflies }\end{array}$ & $\begin{array}{l}0.16 \\
\text { stoneflies, } \\
\text { mayflies }\end{array}$ & $\begin{array}{l}1.34 \\
\text { caddisflies, } \\
\text { mayflies }\end{array}$ & $\begin{array}{c}0.14 \\
\text { mayflies, } \\
\text { stoneflies }\end{array}$ \\
\hline 4 & $\begin{array}{c}0.19 \\
\text { Average }\end{array}$ & $\begin{array}{l}0.08 \\
\text { mayflies, } \\
\text { caddisflies }\end{array}$ & $\begin{array}{c}0.05 \\
\text { mayflies }\end{array}$ & $\begin{array}{l}0.06 \\
\text { mayflies, } \\
\text { caddisflies }\end{array}$ & $\begin{array}{c}0.13 \\
\text { mayflies }\end{array}$ & $\begin{array}{c}0.34 \\
\text { mayflies, } \\
\text { caddisflies }\end{array}$ & $\begin{array}{c}0.11 \\
\text { stoneflies }\end{array}$ & $\begin{array}{l}0.70 \\
\text { caddisflies, } \\
\text { mayflies }\end{array}$ & $\begin{array}{c}0.26 \\
\text { stoneflies }\end{array}$ \\
\hline 5 & $\begin{array}{c}0.19 \\
\text { Average }\end{array}$ & $\begin{array}{c}0.67 \\
\text { mayflies }\end{array}$ & $\begin{array}{c}0.03 \\
\text { stoneflies }\end{array}$ & $\begin{array}{l}0.02 \\
\text { midges }\end{array}$ & $\begin{array}{l}0.23 \\
\text { midges }\end{array}$ & $\begin{array}{c}0.72 \\
\text { mayflies }\end{array}$ & $\begin{array}{c}0.06 \\
\text { stoneflies }\end{array}$ & $\begin{array}{c}0.96 \\
\text { stoneflies }\end{array}$ & $\begin{array}{c}0.18 \\
\text { stoneflies }\end{array}$ \\
\hline 6 & $\begin{array}{c}0.10 \\
\text { Average }\end{array}$ & $\begin{array}{c}0.52 \\
\text { mayflies, } \\
\text { caddisflies }\end{array}$ & $\begin{array}{c}0.10 \\
\text { mayflies }\end{array}$ & $\begin{array}{c}0.48 \\
\text { mayflies, } \\
\text { stoneflies }\end{array}$ & $\begin{array}{l}\quad 0.18 \\
\text { mayflies, } \\
\text { midges }\end{array}$ & $\begin{array}{c}0.22 \\
\text { mayflies }\end{array}$ & $\begin{array}{l}0.10 \\
\text { stoneflies, } \\
\text { midges }\end{array}$ & $\begin{array}{l}0.55 \\
\text { caddisflies, } \\
\text { mayflies }\end{array}$ & $\begin{array}{c}0.44 \\
\text { stoneflies }\end{array}$ \\
\hline 7 & $\begin{array}{l}\text { Below } \\
\text { spray one } \\
\text { mile }\end{array}$ & $\begin{array}{c}0.22 \\
\text { mayflies }\end{array}$ & $\begin{array}{c}1.06 \\
\text { mayflies }\end{array}$ & $\begin{array}{c}0.24 \\
\text { mayflies }\end{array}$ & $\begin{array}{c}0.70 \\
\text { mayflies }\end{array}$ & $\begin{array}{c}0.31 \\
\text { mayflies }\end{array}$ & $\begin{array}{c}0.06 \\
\text { stoneflies }\end{array}$ & $\begin{array}{l}0.34 \\
\text { caddisflies, } \\
\text { mayflies }\end{array}$ & $\begin{array}{c}0.18 \\
\text { stoneflies }\end{array}$ \\
\hline 8 & $\begin{array}{l}\text { Below } \\
\text { spray, 1- } \\
1 / 8 \text { miles }\end{array}$ & $\begin{array}{c}1.62 \\
\text { mayflies }\end{array}$ & $\begin{array}{c}0.57 \\
\text { mayflies }\end{array}$ & $\begin{array}{c}0.32 \\
\text { mayflies }\end{array}$ & $\begin{array}{c}0.50 \\
\text { mayflies }\end{array}$ & $\begin{array}{c}0.74 \\
\text { mayflies }\end{array}$ & $\begin{array}{c}0.26 \\
\text { stoneflies, } \\
\text { craneflies }\end{array}$ & $\begin{array}{l}1.22 \\
\text { caddisflies, } \\
\text { mayflies }\end{array}$ & $\begin{array}{c}0.54 \\
\text { stoneflies } \\
\text { caddisflies }\end{array}$ \\
\hline 9 & $\begin{array}{l}\text { Below } \\
\text { spray } 1 \frac{1}{2} \\
\text { miles }\end{array}$ & $\begin{array}{l}1.13 \\
\text { mayflies, } \\
\text { caddisflies }\end{array}$ & $\begin{array}{c}0.87 \\
\text { mayflies }\end{array}$ & $\begin{array}{c}0.18 \\
\text { mayflies }\end{array}$ & $\begin{array}{c}0.69 \\
\text { mayflies }\end{array}$ & $\begin{array}{c}0.66 \\
\text { mayflies }\end{array}$ & $\begin{array}{c}0.24 \\
\text { stoneflies }\end{array}$ & $\begin{array}{c}0.78 \\
\text { mayflies, } \\
\text { stoneflies }\end{array}$ & $\begin{array}{c}0.40 \\
\text { stoneflies }\end{array}$ \\
\hline
\end{tabular}

I) Spray reaching ground July 2, 1956. 
Table 15 - Summary of mortality of insects and fish in live cars Canyon and Trapper Creeks

\begin{tabular}{|c|c|c|c|c|}
\hline \multicolumn{3}{|c|}{$\begin{array}{lc}\text { Sprayed } 7 / 2 / 56 & (4-6 \text { a.m. }) \\
\text { Live car } & \text { DDT Spray } \\
\text { (fish \& } & \text { (average Ibs. } \\
\text { insect) } & \text { per acre } \\
& \text { reaching stream) } \\
\end{array}$} & $\begin{array}{l}\text { Mortality of } \\
\text { insects } 24 \mathrm{hrs} \text {. } \\
\text { after spraying } \\
\text { (percent) } \\
7 / 3 / 56\end{array}$ & $\begin{array}{l}\text { Mortality of } \\
\text { fish } 5 \text { days } \\
\text { after spraying } \\
7 / 6 / 56\end{array}$ \\
\hline \multicolumn{5}{|c|}{ CANYON CREEK } \\
\hline I & & 0 & 0 & 0 \\
\hline II & & 0.01 & 90 & 0 \\
\hline III & & 0.32 & 66 & 0 \\
\hline IV & & 0.32 & 66 & 0 \\
\hline V & & 0.32 & 66 & 0 \\
\hline VI & & 0.32 & 50 & 0 \\
\hline VII & & 0.32 & 0 I & 0 \\
\hline VIII & - & 0 & 0 & 0 \\
\hline \multicolumn{5}{|c|}{ TRAPPER CREEK } \\
\hline I & & 0.19 & 33 & 0 \\
\hline II & & 0.19 & 20 & 0 \\
\hline III & & 0.10 & 20 & 0 \\
\hline IV & & 0 & $0 \leq$ & 0 \\
\hline $\mathrm{V}$ & & 0 & 10 & 0 \\
\hline VI & & 0 & 0 & 0 \\
\hline VII & & 0 & 0 & 0 \\
\hline VIII & & 0 & 0 & 0 \\
\hline
\end{tabular}

I/ $\mathrm{All}$ insects were caddisflies which pupated.

2) No mortality, but insects seemed to be affected. 
Table 16 - Numbers of adult aquatic insects collected by sweep net at Canyon Creek, 1956

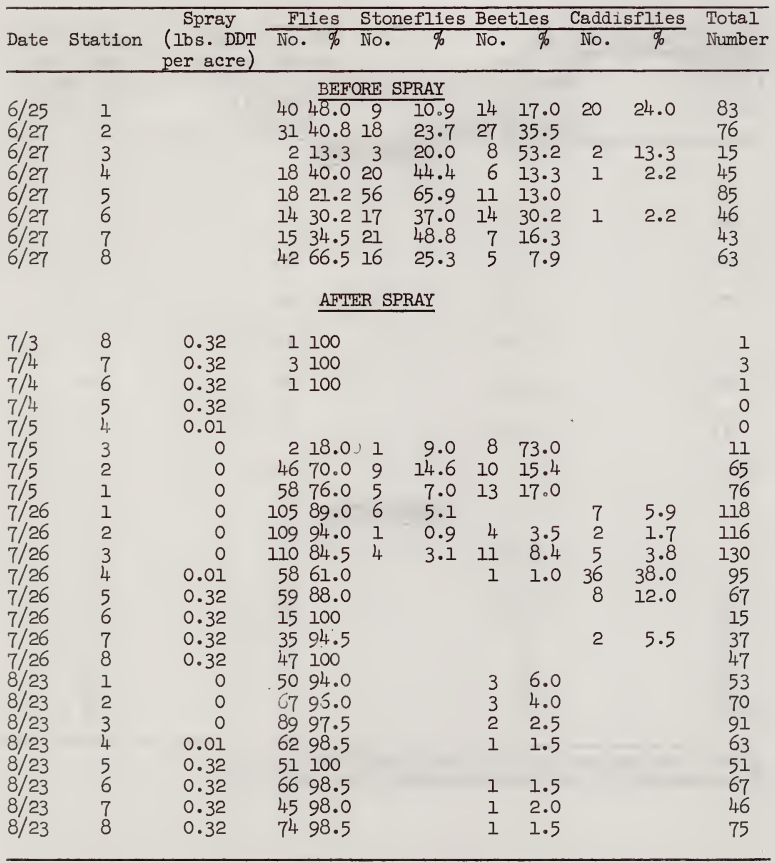


Table 17 - Numbers of adult aquatic insects collected by sweep net at Trapper Creek, 1956

\begin{tabular}{ccccccc}
\hline Spray & Flies & Stoneflies Beetles & Caddisflies & Total \\
Date Station (Ibs. DDT No. \% No. $\%$ No. $\%$ & No. $\%$ & Number
\end{tabular} per acre)

BEFORE SPRAY

$6 / 26 \quad 8$

$6 / 27 \quad 5$

$6 / 27 \quad 6$

$6 / 27 \quad 7$

$6 / 27 \quad 9$

$6 / 29 \quad 2$

$6 / 29 \quad 3$

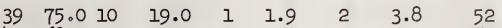

$\begin{array}{lllllll}43 & 68.0 & 17 & 27.0 & 3 & 5.0 & 63\end{array}$

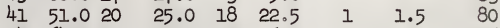

$\begin{array}{llllllll}74 & 64.0 & 35 & 30.0 & 7 & 6.0 & & \end{array}$

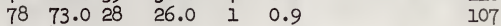

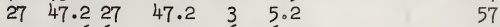

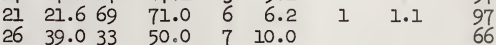

AFITER SPRAY

$\begin{array}{llllllllllll}7 / 3 & 8 & 0 & 9 & 69.2 & 1 & 7.7 & 1 & 7.7 & 2 & 15.4 & 13\end{array}$

$\begin{array}{lllllllll}7 / 3 & 9 & 0 & 12 & 60.0 & 5 & 25.0 & 3 & 15.0\end{array}$

$\begin{array}{lllllllll}7 / 4 & 2 & 0.19 & 22 & 78.6 & 2 & 7.1 & 4 & 14.3\end{array}$

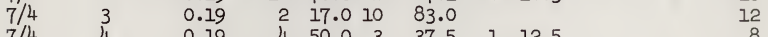

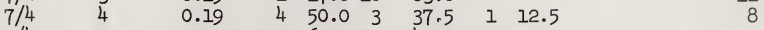

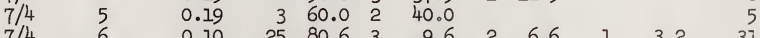

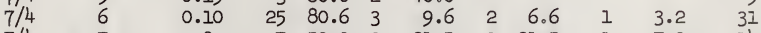

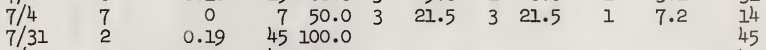

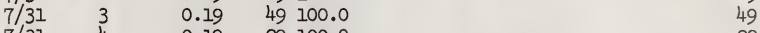

$\begin{array}{lllll}7 / 31 & 4 & 0.19 & 29 & 100.0\end{array}$

$\begin{array}{lllllll}7 / 31 & 5 & 0.19 & 17 & 89.5 & 2 & 10.5\end{array}$

$\begin{array}{llllllll}7 / 31 & 6 & 0.10 & 15 & 68.0 & 7 & 32.0 & 22\end{array}$

$\begin{array}{lllllll}7 / 31 & 7 & 0 & 49 & 96.0 & 2 & 4.0\end{array}$

$\begin{array}{lllllll}7 / 31 & 8 & 0 & 35 & 89.7 & 4 & 10.3\end{array}$

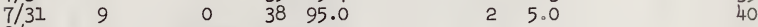

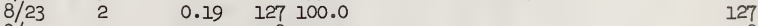

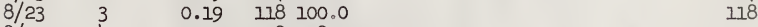

$\begin{array}{lllllll}8 / 23 & 4 & 0.19 & 78 & 98.7 & 1 & 79\end{array}$

$8 / 23 \quad 5 \quad 0.19 \quad 57100.0^{\text {mayfly }}$

$\begin{array}{llllllllll}8 / 23 & 6 & 0.10 & 60 & 95.0 & 1 & 1.5 & 2 & 3.0 & 63\end{array}$

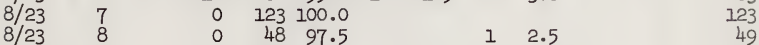

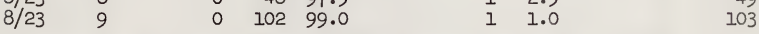


Table 18 - Voiunes (cr.) per Bquare font of stream invertebrates collected in bottom samples, Heiena, Iewls \& Clark and Beaverhead Nationa? Forests, 1956-1957.

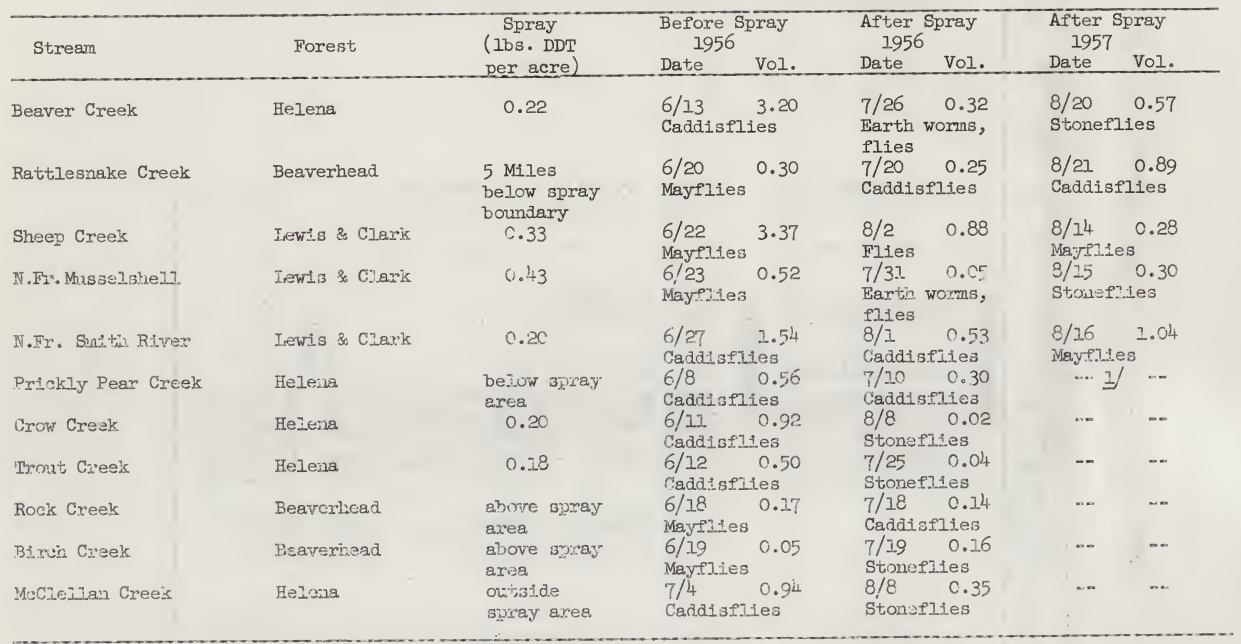

If Not sampled in 1957 because of envitronmontal ohanges. 
Table 19 - Numbers of game fish collected in five streams by shocking $1956-1957$

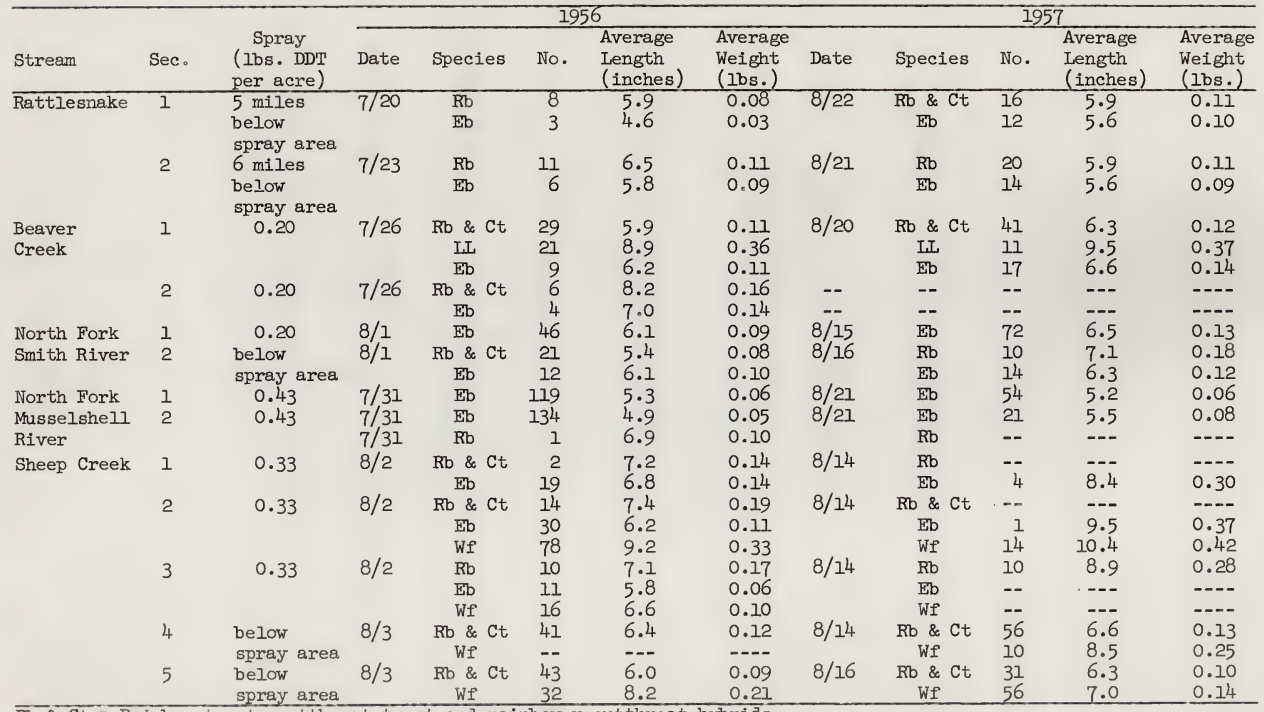

$\overline{\mathrm{Rb}} \& \mathrm{Ct}=$ Rainbow trout, cutthroat trout and rainbow $\mathrm{x}$ cutthroat hybrids.

$\mathrm{Eb}=$ Eastern brook trout; $\mathrm{LL}=$ Loch
$\mathrm{Ct}=$ Cutthroat trout; $\mathrm{Wf}=$ Whitefish 


